\title{
ECONOMICS
}

\section{AN AUSTRALIAN CONTRIBUTION TO INTERNATIONAL TRADE THEORY: THE DEPENDENT ECONOMY MODEL}

by

Phillip Edmund Metaxas

Business School University of Western Australia

and

Ernst Juerg Weber Business School University of Western Australia 


\author{
by \\ Phillip Edmund Metaxas \\ and \\ Ernst Juerg Weber \\ Business School \\ University of Western Australia \\ Crawley WA 6009
}

May 2013

DISCUSSION PAPER 14.02

We would like to thank Ken Clements for helpful comments. 


\begin{abstract}
This paper details the origin and development of the dependent economy model. The model is also known as the 'Australian model' and the 'Salter-Swan-Corden-Dornbusch model', but neither title adequately conveys the scope and sequence of contributions that were instrumental to its development. In particular, attention is given to indispensable contributions made by Australian public servant Sir Roland Wilson and British economist James Meade, which preceded those of Trevor Swan, Wilfred Salter, W. Max Corden and Rudiger Dornbusch. It is shown that Wilson and Meade laid much of the theoretical groundwork ahead of the contributions of Swan, Salter, Corden and Dornbusch. Each contribution is analysed in detail and the model's development is placed in the broader context of the evolution of balance of payments theory. The paper sheds light on several underappreciated (or perhaps unknown) facets of the model and, principally, highlights a broader Australian contribution to international trade theory inherent in it, namely, the identification of the real exchange rate as the critical relative price in balance of payments adjustment.
\end{abstract}




\section{Table of Contents}

Introduction 1

1. Roland Wilson and the Mechanism of Adjustment ……………………….................. 3

2. Balance of Payments Theory in the Interwar Years....................................................... 12

3. James Meade's The Balance of Payments.................................................................... 17

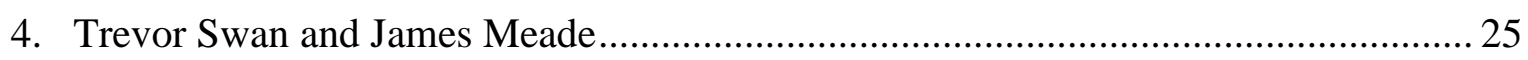

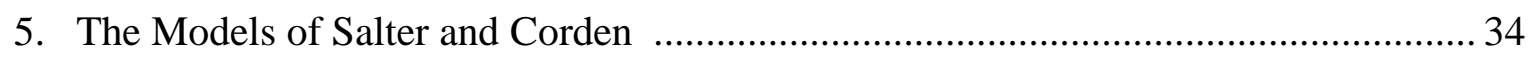

6. A Non-Traded Export: The Dependent Economy Model Abroad .................................. 43

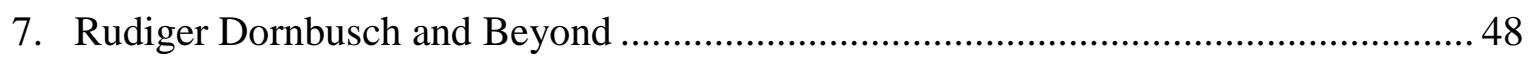

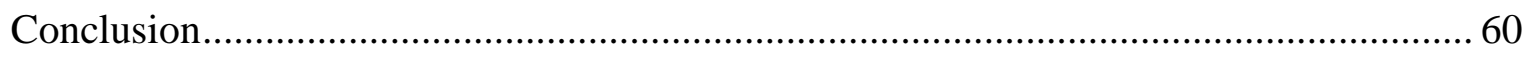

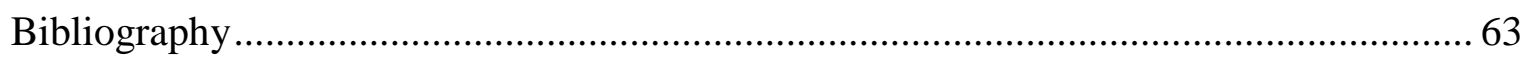




\section{Introduction}

The dependent economy model was formally developed by Australian economists in the 1950s and early 1960s and remains the core theoretical framework for economic analysis in small open economies. It is well known through the 'Salter model' and 'Swan diagram' and is commonly used for economic policy analysis and the analysis of external shocks. Less appreciated, however, is the interesting history behind the model's origin and development a history inextricably tied to the evolution of balance of payments theory. The development of the model is generally credited to Wilfred Salter (1959), Trevor Swan (1960, 1963a), W. Max Corden (1960) and Rudiger Dornbusch (1974, 1980), but indispensable earlier contributions were made by renowned Australian public servant Sir Roland Wilson (1931) and British economist James Meade (1951). This paper details the sequence of contributions critical to the model's development (from Wilson-Meade-Swan-Salter-Corden-Dornbusch) and places them in the broader context of the evolution of balance of payments theory. In addition, it highlights an underappreciated (or perhaps unknown) Australian contribution to international trade theory inherent in the dependent economy model.

It is shown that Roland Wilson foreshadowed many of the crucial features of the model when he published a book in 1931 that offered a theoretical objection to a position held by Frank Taussig and Jacob Viner, two leading international trade theorists of the time. Taussig and Viner had followed the classical economists in suggesting balance of payments equilibrium was maintained through movements in the terms of trade. Wilson, who studied for a doctorate under Viner at the University of Chicago, offered an alternative explanation that emphasised a different price ratio, the relative price between domestic goods and internationally traded goods.

Viner, writing in 1937, rejected Wilson's argument but acknowledged a new strand of thought which emphasised the role played by income/expenditure effects in balance of payments adjustment. These two strands of thought - terms of trade and income adjustments - were refined in the interwar years and integrated by James Meade in 1951, when he published the standard international economics text of the period. Meade's principal contribution (there were several) was the introduction of two policy targets: internal and external balance. These concepts became fundamental to the subsequent contributions made by Australians Swan, Salter and Corden. 
Though Salter's paper was the first to be published, Swan first responded to James Meade's text with two separate seminar papers in 1953 and 1955, published in 1960 and 1963 respectively. Swan, who was appointed the inaugural head of the department of economics at the Australian National University (ANU) in 1950, was heavily influenced by James Meade's analysis but objected to his emphasis on terms of trade adjustments by invoking Roland Wilson's argument from two decades prior. Swan was able to convert Meade to his view, and his contributions inspired related theoretical work by Salter (1959) and Corden (1960). All three models by Swan, Salter and Corden are characterized by their emphasis on Wilson's relative price.

The model's recognition abroad is an interesting story in itself. The initial intellectual credit went to Ivor Frank Pearce, a member of Swan's department at the ANU who in 1961 published a thematically similar article that did not cite the previous contributions made by his ANU colleagues, Swan and Salter. This led some international scholars to erroneously cite Pearce as the originator of the Australian approach, which meant the contributions made by the other Australians were not fully appreciated for a number of years. Rudiger Dornbusch appears to be the first international scholar to acknowledge the related Australian contribution. He made a series of refinements to the model and contributed greatly to its popularity by including it in his textbook Open Economy Macroeconomics (1980), where he redefined the relative price central to the dependent economy model as 'the real exchange rate'. Thus the Australian contribution to international trade theory is the identification of the real exchange rate as the critical relative price in balance of payments adjustment.

This dissertation proceeds as follows: section one explains the classical terms of trade mechanism and analyses Roland Wilson's contribution; section two outlines the evolution of the terms of trade mechanism and the emergence of the income adjustment mechanism in the interwar years; section three explains crucial elements of James Meade's The Balance of Payments (1951) and identifies an important critique that followed its publication; section four details Trevor Swan's contributions and Meade's subsequent acceptance of the Australian approach; section five explains the contributions made by Salter and Corden and highlights important enhancements on prior contributions; section six describes how the Australian approach was recognised abroad in the 1960s; and section seven analyses Rudiger Dornbusch's contribution and highlights more recent research which has emerged from the model. 


\section{Roland Wilson and the Mechanism of Adjustment}

\section{Sir Roland Wilson}

Sir Roland Wilson was born in Ulverston, Tasmania in $1904^{1}$. In 1932 he was hired as an economist in the Statistician's Branch of the Australian Treasury, beginning a distinguished career in the Australian Public Service. He quickly rose to the position of Assistant Commonwealth Statistician, and in 1936 he was promoted to Commonwealth Statistician, a position he held until 1951. During the war years, Wilson championed and served on a committee that provided advice to the government on the economic management of the war, as well as guidance on post-war reconstruction. In 1940 he headed the newly created Department of Labour and National Service, where he established a division on post-war reconstruction. Wilson's involvement in post-war planning saw him represent Australia at the first British Commonwealth conference on the international economy in the post-war era, held in London in 1942. He also attended the two-month-long conference held in San Francisco in 1945 that led to the creation of the United Nations. In 1951 he was appointed Secretary to the Treasury, a position he held until his retirement from the public service in 1966. He remains the longest serving Secretary of the department. Wilson went on to serve as chairman of Qantas and the Commonwealth Bank, before board appointments at other companies. He died in Canberra in 1996.

While Wilson is best remembered as a public servant, it was during his time as a student that he made his contribution to economic theory. Wilson began his tertiary education in his home state, studying commerce at the University of Tasmania ${ }^{2}$. He graduated with first-class honours and was awarded the Tasmanian Rhodes Scholarship in 1925. At Oxford he completed a Diploma in Economics and Political Science prior to enrolling for a doctorate. His thesis, titled 'The Import of Capital', was supervised by Eric Hargreaves and accepted in 1929. After Oxford, Wilson was awarded a scholarship to continue postgraduate study at the University of Chicago, where he completed a second doctorate in 1930. His Chicago thesis, which was supervised by Jacob Viner and titled 'Capital Movements and their Economic Consequences', built on some of the themes outlined in his Oxford thesis (Cornish 2007b, p.

\footnotetext{
${ }^{1}$ Biographical information on Sir Roland Wilson can be found in Cornish (2002, 2007b).

${ }^{2}$ James Bristock Brigden was one of Wilson's lecturers at the University of Tasmania. He was the lead author of an influential report on Australia's system of tariffs, published as The Australian Tariff: An Economic Enquiry (1929). In this report, Brigden anticipated the Stolper-Samuelson theorem by arguing that a tariff could raise real wages.
} 
311). The core themes of his two doctoral theses were later combined in a book, Capital Imports and the Terms of Trade (1931).

\section{Capital Imports and the Terms of Trade}

The book is made up of five chapters, including an introduction: chapters II and III are devoted to an estimate of the net importation of capital into Australia between 1871-1930; chapter IV provides a theoretical framework regarding the effects of capital flows on price levels and the balance of payments; and chapter $\mathrm{V}$ attempts to verify theoretical predictions against Australian data. The ideas advanced by Wilson in chapter IV went against economic orthodoxy. The effects of capital flows on price levels and the balance of payments had been discussed by classical economists such as John Stuart Mill, and the classical view was supported by two of the leading figures in international trade theory at the time: Frank Taussig (1859-1940) and, Wilson’s supervisor, Jacob Viner (1892-1970). The two men were close, both intellectually and personally ${ }^{3}$. Taussig, who studied at Harvard before commencing a long and distinguished academic career at the same university, had pursued the theoretical consequences of capital flows in journal articles (see Taussig 1917, 1920) and was interested in confirming his predictions against empirical evidence. Viner offered such a study in the form of his Harvard $\mathrm{PhD}$ thesis, which Taussig supervised. Both men published books in the 1920s that dealt with the theoretical dilemma of interest to Wilson. Viner's book, titled Canada's Balance of International Indebtedness 1900-1913 (1924) was a published version of his PhD thesis. Taussig's, titled International Trade (1927), was an extensive international trade text that, inter alia, expanded on his previous writings on the subject and included a chapter devoted to Viner's $\mathrm{PhD}$ study. It was the theoretical conclusions regarding capital flows of these two texts, heavily influenced by the classical writers, which Wilson sought to challenge.

\section{The Mechanism of Adjustment}

The central theoretical question pursued by Wilson was the mechanism through which balance of payments equilibrium would be restored after a capital flow (e.g., loan) from one country to another - what Viner (1924) called 'the mechanism of adjustment'. Equilibrium in the balance of payments simply means that payments to foreigners are matched by equivalent receipts from foreigners. Beginning with balance of payments equilibrium, a capital flow

\footnotetext{
${ }^{3}$ Viner dedicated his Studies in the Theory of International Trade (1937) to 'Frank Taussig, teacher and friend'.
} 
from country A to country B causes an excess of payments over receipts in A (deficit) and an excess of receipts over payments in B (surplus). Wilson was concerned with how equilibrium would be restored, or, as he put it, how the loan would be transferred 'in the form of goods' (Wilson 1931, p. 55). His terminology is reflective of the period, but in modern parlance he is asking how, in the case of the borrower, a capital account surplus is matched by an offsetting current account deficit (and the opposite for the lender) to maintain equilibrium in the balance of payments. On this question, classical economists offered an answer through the pricespecie-flow mechanism.

\section{The Price-Specie-Flow Mechanism}

The price-specie-flow mechanism is attributed to David Hume, who explained the mechanism by considering the consequences of the British money supply shrinking by four-fifths or growing five-fold overnight (Hume 1752, pp. 84-105). In the first case, the reduction in money would cause British prices and wages to fall (an example of the quantity theory of money), making exports more attractive to foreigners. This would lead to an excess of exports over imports and a balance of payments surplus, thus resulting in specie (gold) being shifted from the rest of the world to Britain. This process would return what Hume called the 'level of money' to its equilibrium state. Hence the price-specie-flow mechanism corrects balance of payments disequilibria through an automatic process whereby gold is transferred from the deficit country to the surplus country. This raises prices in the surplus country and reduces prices in the deficit country. Hume's view was endorsed by classical economists such as Henry Thornton, Thomas Malthus and John Stuart Mill; however, Viner (1924, pp. 191-202) describes an interesting difference of opinion regarding the adjustment process between Thornton and Malthus on one side and David Ricardo on the other. The view of Hume and his followers on the question of capital flows was summarised by Mill as follows:

Commerce being supposed to be in a state of equilibrium when the obligatory remittances begin, the first remittance is necessarily made in money. This lowers prices in the remitting country, and raises them in the receiving. The natural effect is that more commodities are exported than before, and fewer imported, and that, on the score of commerce alone, a balance of money will be constantly due from the receiving to the paying country. When the debt thus annually due to the tributary country becomes equal to the annual tribute or other regular payment due from it, no further transmission of money takes place; the equilibrium of exports and imports will no longer exist, but that of payments will; the exchange will be at a par, the two debts will 
be set off against one another, and the tribute or remittance will be virtually paid in goods. (Mill 1871, Bk. III, Chap. XXI, § 4)

Returning to the example of countries A and B, Mill is stating that the capital flow causes money to move from A to B, leading to lower prices in A and higher prices in B. This lowers the price of A's exports and increases the price of B's exports (A's imports), leading to an increase in A's exports and a reduction in B's. This continues until the trade surplus in A offsets the capital flow so that the balance of payments is in equilibrium. Implicit within Mill's explanation is that the terms of trade - the price of exports relative to imports - moves in favour of the borrower and against the lender. This changing relative price, then, is the mechanism that restores balance of payments equilibrium.

\section{Frank Taussig and Jacob Viner}

Mill's view, which stressed the terms of trade as the mechanism that restored balance, was supported by Viner and Taussig. The purpose of Viner's book was to test the predictions espoused by the classical writers with Canadian data from 1900-1913. His conclusions were summarised as follows:

It has already been shown that, according to those economists who follow Thornton and Mill rather than Ricardo in their explanation of the mechanism of adjustment of international balances, prices during a period of capital borrowings rise in the borrowing country, fall in the lending country. This theory has been verified inductively for Canada during the period 1900 to 1913, and it has also been shown that domestic and export prices rose relatively to import prices. It is a corollary of this reasoning that during a period of international borrowings the terms of international exchange shift in favour of the borrowing country and against the lending country - in other words, that the borrowing country obtains more foreign produce in exchange for each unit of its exports than it did prior to the period of borrowing. (Viner 1924, p. 295)

Viner's reference to domestic, export and import prices will be discussed shortly. His conclusion, however, was a firm endorsement of the view held by the classical writers and Taussig: the mechanism of adjustment that restores balance of payments equilibrium is an unfavourable movement in the terms of trade for the lender and a favourable movement in the terms of trade for the borrower.

Like Viner, Taussig discussed the effects of capital flows under a gold standard in his book, and his view was consistent with the price-specie-flow mechanism (Taussig 1927, pp. 123140). More unique, however, was his analysis of the mechanism of adjustment under paper 
currencies in a system of flexible exchange rates between countries - a topic he felt the classical writers had neglected (Taussig 1927, pp. 337-362). Taussig reasoned that, since the absence of a gold standard would eliminate the need for specie to move across nations, the mechanism of adjustment under paper currencies must in some way be different. The example used was a hypothetical loan from Great Britain to the United States, taking place after initial balance of payments equilibrium. He assumed that the money supply remained constant in both countries so that the prices of domestically produced commodities remained unchanged (the quantity theory of money). The effect of the capital flow, from the perspective of the borrowing country, is described as follows:

In New York sterling exchange falls; and Americans who have sold goods to British customers and who have sterling exchange to sell, get less dollars than before. Side by side with the tendency toward greater exports from Great Britain into the United States there will be a tendency toward less exports from the United States into Great Britain. (Taussig 1927, p. 347)

Observe further (still having regard to the ultimate outcome) that the goods exported from the United States to Great Britain, tho [sic] dearer in Britain, are unchanged in price in the United States. Similarly, the goods exported from Great Britain, tho [sic] cheaper in the United States, are the same price in Great Britain. The altered prices - American imports dearer in Great Britain, British imports cheaper in the United States - are altered solely because of the new rates of foreign exchange. (Taussig 1927, p. 353)

The capital flow leads to an appreciation of the borrower's currency and a depreciation of the lender's currency. This makes imports more attractive in the borrowing country so that, as with the price-specie-flow mechanism, an excess of exports over imports results in the lending country. How, then, does the mechanism differ between the gold standard and paper currencies? Taussig argued that the difference between the two revolves around the movement of domestic prices (including exports). Under the price-specie-flow mechanism, the outflow of gold in the lending country reduces domestic prices and this causes the positive trade balance. With paper currencies, the domestic price level is assumed fixed in both countries (as the money supply is constant). However, the movement in the exchange rate lowers the domestic price of imports in the borrowing country and increases the domestic price of imports in the lending country. Hence the mechanism of adjustment is really no different. From the perspective of the borrowing country, export prices stay constant and import prices fall. From the perspective of the lending country, export prices stay constant and import prices rise. The result is that the terms of trade move favourably for the borrowing 
country and unfavourably for the lending country: the mechanism of adjustment is the same under a gold standard or paper currency regime.

\section{Domestic Goods}

Wilson challenged this theoretical argument by invoking the concept of 'domestic goods' Viner (1937, p. 323) suggests the distinction between domestic and international goods dates 'at least' back to Ricardo, and Cairnes (1874, p. 409) provides a lucid theoretical explanation why some goods enter international trade and some do not by emphasising the role played by transportation costs. Viner (1924, pp. 206-212) and Taussig (1927, pp. 34-42) also invoked transportation costs to explain domestic and international commodities, and the former's explanation is worthy of elaboration. Consider a commodity, say wheat, which is produced in both Chicago and Liverpool. The price of wheat in Liverpool is \$2 and remains unchanged. The cost of transportation between the two cities (in either direction) is 40 cents. This means that the Chicago price of wheat can range from $\$ 1.60$ to $\$ 2.40$ while still remaining a domestic good. To see the logic, at a price of $\$ 1.60$ Chicago wheat costs the same to British importers as Liverpool wheat, so they are indifferent between the two. Only if the price of Chicago wheat fell below $\$ 1.60$ would it be imported into Liverpool (exported from Chicago). Similarly, at a price of $\$ 2.40$ American importers would be indifferent between Chicago wheat and imported Liverpool wheat. Only if the Chicago price rose above $\$ 2.40$ would wheat be imported from Liverpool. This simple example highlights that the classification of a commodity as either domestic or internationally traded is fluid and is a function of domestic prices, foreign prices and transportation costs. As these factors change, so too can a commodity's classification ${ }^{4}$.

\section{Wilson's Framework}

Wilson well understood the logic employed by his second $\mathrm{PhD}$ supervisor, and the distinction between domestic and internationally traded commodities would form the centrepiece of this theoretical argument. He contended that the mechanism of adjustment that restored balance after a capital flow was not the terms of trade but instead the price of domestic goods relative international goods. He illustrated his point by considering a loan between two imaginary countries, Dives (the lender) and Lazarus (the borrower), taking place after initial equilibrium in the balance of payments. Each country produces domestic and international goods, and

\footnotetext{
${ }^{4}$ Dornbusch (1980, pp. 94-95) provides an algebraic and graphical analysis of the distinction between domestic and international goods.
} 
expenditure in each country can be assigned between three types of goods: exportables produced at home, domestic goods produced at home, and exportables produced abroad (imports). This is displayed in figure 1:

Figure 1: Wilson's Two-country Model

\begin{tabular}{|c|l|c|l|}
\hline \multicolumn{2}{|c|}{ Dives } & \multicolumn{1}{c|}{ Lazarus } \\
\hline Good & \multicolumn{1}{|c|}{ Description } & Good & \multicolumn{1}{c|}{ Description } \\
\hline A div & $\begin{array}{l}\text { Exportable goods produced in Dives and } \\
\text { consumed there }\end{array}$ & A laz & $\begin{array}{l}\text { Exportable goods produced in Lazarus and } \\
\text { consumed there }\end{array}$ \\
\hline B div & $\begin{array}{l}\text { Domestic goods produced and consumed in } \\
\text { Dives }\end{array}$ & B laz & $\begin{array}{l}\text { Domestic goods produced and consumed in } \\
\text { Lazarus }\end{array}$ \\
\hline C div & $\begin{array}{l}\text { Exportable goods produced in Lazarus and } \\
\text { consumed in Dives }\end{array}$ & C laz & $\begin{array}{l}\text { Exportable goods produced in Dives and } \\
\text { consumed in Lazarus }\end{array}$ \\
\hline
\end{tabular}

The A and C goods enter international trade but the B goods in each country do not. The upshot is that prices of $\mathrm{A}$ and $\mathrm{C}$ goods must be the same in both countries (after allowing for transportation costs and duties), but the prices of domestic goods can vary. The summation of expenditure in each country on A, B and C goods is referred to by Wilson as 'total spendable resources' - what would now be called domestic expenditure or absorption. The effect of a loan from Dives to Lazarus is to reduce total spendable resources in Dives and increase total spendable resources in Lazarus. The question, then, is how this transfer of expenditure affects the prices of commodities and the balance of payments.

\section{Wilson’s Mechanism of Adjustment}

Wilson began by ignoring the existence of domestic goods in either country and argued in three examples that the loan could theoretically lead to no change in the terms of trade (example I), a favourable movement in the terms of trade for the borrower (example II), or an unfavourable movement in the terms of trade for the borrower (example III). Thus he challenged the necessity for the terms of trade to move favourably for the borrower even within the two-commodity, two-country framework that Taussig had used. Yet the core of Wilson's argument was outlined in a fourth example that included domestic goods in both countries. He argued that the effect of a loan from Dives to Lazarus was to lower the price of domestic goods relative to international goods in the lending country and raise the price of domestic goods relative to international goods in the borrowing country. It was this relative price - not the terms of trade - that restored balance of payments equilibrium. 
But in each country there is now another factor in operation. In Dives there is a fall in price of $\mathrm{B}$ div goods relatively to the prices of both $\mathrm{A}$ and $C$ goods; and in Lazarus there is a rise in the prices of $B$ laz goods relatively to the prices of both $\mathrm{A}$ and $\mathrm{C}$ goods. As a result, demand in Dives will be diverted from $\mathrm{A}$ and $\mathrm{C}$ goods and transferred to $\mathrm{B}$ div, or domestic, goods, which have become relatively cheaper. Conversely, demand in Lazarus will be diverted from B laz, or domestic, goods and transferred to $\mathrm{A}$ and $\mathrm{C}$ goods, which have become relatively cheaper in Lazarus ... Certain changes in production may be expected to follow from these initial price tendencies. In Dives B div and A goods are produced: with B div prices falling relatively to A prices, productive effort will be transferred from B div to A goods. In addition to the diminished demand in Dives for A goods, there is now an increase in the supply, and thus a greater exportable surplus of $\mathrm{A}$ goods is produced. Conversely, in Lazarus B laz and C goods are produced: with B laz prices rising relatively to $\mathrm{C}$ prices, productive effort will be transferred from $\mathrm{C}$ goods to $\mathrm{B}$ laz goods. In addition to the increased demand in Lazarus for $\mathrm{C}$ goods, there is now a decrease in the supply, and thus a smaller exportable surplus of $\mathrm{C}$ goods is produced. (Wilson 1931, pp. 74-75)

Wilson argued that the change in the price of domestic goods relative to international goods would initiate consumption and production responses that lead to a trade surplus in the lending country and a trade deficit in the borrowing country. Taking the case of Lazarus (the borrower), diverting expenditure from the relatively expensive domestic goods to $\mathrm{A}$ and $\mathrm{C}$ goods helps create a trade deficit in two ways: first, higher expenditure on A goods increases imports; second, higher expenditure on C goods (domestically produced exportables) reduces the surplus available to export. This is supplemented on the production side because higher relative prices for domestic goods leads to increased production of those goods and lower production of exportables, once again reducing exports.

\section{Wilson on the Terms of Trade}

Wilson thought the role played by the terms of trade was incidental to the actual mechanism of adjustment: the price of domestic goods relative to international goods. His belief in the unimportance of the terms of trade was justified theoretically with two amendments to the model used above. First, he allowed the production of $\mathrm{A}$ and $\mathrm{C}$ goods in both countries, labelling the class of goods that could previously only be imported as 'importables'. Second, he assumed that one of the countries (Lazarus) was very small in relation to the other (Dives), which meant the model in effect depicted Lazarus against the rest of the world. On this assumption Wilson wrote: 
Where such is the case - and it will be the case unless Lazarus provides the main source of supply for $\mathrm{C}$ goods, or the main source of demand for A goods - two conclusions emerge:

i) A goods cannot change very much in price on account of altered conditions of supply or demand in Lazarus; i.e., the elasticity of world supply to a single country is great.

ii) C goods cannot change very much in price on account of altered conditions of supply or demand in Lazarus; i.e., the elasticity of world demand from a single country is great.

... The actual import and export price-levels of any particular country, therefore, and especially of an economically unimportant country, cannot be very effectively influenced by conditions within the country itself; and in practice we should expect any effects of such influences to be overlaid and obscured by the effects of changes in world conditions of supply and demand. (Wilson 1931, p. 79)

Wilson's argument is that a small country would face highly elastic demand for its exports and highly elastic supply for its imports. The implication is that conditions within the small country are likely to have little influence on the internationally determined prices of its exports and imports. Therefore, any changes in Lazarus' demand for or supply of international goods caused by the capital flow will be dominated by conditions in world markets for international goods. Since this means the terms of trade of a small country are effectively fixed, it is unlikely that the terms of trade is the relative price that restores balance of payments equilibrium.

Yet Wilson stopped short of drawing definitive theoretical conclusions. He believed he had the shown the possibility that the terms of trade could move in either direction or remain constant, but the actual movement was contingent upon the particular circumstances of the case. Nevertheless, he believed that domestic commodities would comprise a large proportion of domestic expenditure, thus making it more likely that the prices of domestic commodities would rise relative to international commodities in the case of capital inflow. Wilson devoted chapter $\mathrm{V}$ of his book to an empirical analysis of his predictions with Australian data. He concluded that there was no consistent correlation - positive or negative - between capital inflows and the terms of trade, but he found that capital inflows tended to be positively correlated with an increase in the ratio of domestic to international prices, which was consistent with his theoretical assertion. 


\section{Balance of Payments Theory in the Interwar Years}

\section{Viner Responds to Wilson}

Wilson had offered a bold theoretical objection to the orthodox view, but his supervisor was not convinced. Writing years later in his classic Studies in the Theory of International Trade (1937), Viner devoted several pages to a discussion of Wilson's analysis. He objected to Wilson's position with two separate arguments (Viner 1937, pp. 327-332). First, after stating Wilson's view that the key relative price in the mechanism of adjustment was not the terms of trade but instead the price of domestic goods relative to international goods, Viner then offered this opinion in a dismissive footnote: 'That this proposition is incorrect can be sufficiently shown by the reductio ad absurdum to which it would lead if there were more no domestic commodities' (Viner 1937, p. 327). Viner's objection was logical: how could domestic goods play a key role in the mechanism of adjustment in countries where they do not exist? In other words, if all goods enter into international trade, how could a relative price that includes domestic goods be of any relevance? His second argument disputed Wilson's findings along familiar grounds. Viner maintained that the capital flow from Dives to Lazarus would lead to a general fall in prices in Dives (exportables and domestic goods) as well as a general increase in prices in Lazarus, just as they would under the price-specie-flow mechanism. Viner did not believe that the price of domestic goods relative to exportables (the goods produced in each country) could change permanently, since both industries competed for the same factors of production. Higher prices for domestic goods in the borrowing country, as predicted by Wilson, would cause factors of production to move from the exportable sector to the domestic sector until factor prices equalised. This would ensure that the prices of exportables and domestic goods would move proportionately. Viner's second objection appears to have been a longstanding cause of conflict between student and supervisor. Wilson addressed this objection in his book (Wilson 1931, pp. 76-77) but did not refer to Viner by name. Nevertheless, he argued that increased money costs of production would not necessarily lead to higher prices, since relative prices would only change if demand and supply in the overall market were affected. 


\section{Another Mechanism of Adjustment}

Despite Wilson's best efforts, Viner maintained that the terms of trade was the key relative price in the mechanism of adjustment. He did, however, concede that the terms of trade was not the sole equilibrating force. At that time, a new theory of adjustment had emerged - which Viner credited primarily to the work of Bertil Ohlin - that emphasised the role played by 'relative demands' (income/expenditure effects) in restoring balance of payments equilibrium. Ohlin $^{5}$ (1929) had articulated his theory in response to a pessimistic article Keynes (1929) had written about Germany's ability to finance continuing reparations payments, and this kickstarted a controversial debate on the subject between Keynes and Ohlin in the Economic Journal. Ohlin argued that the effect of German reparations payments on the balance of payments would be offset, perhaps entirely, through higher expenditure in the receiving country and lower expenditure in Germany. The higher expenditure ('purchasing power') in the receiving country would lead to increased imports from Germany, and the lower expenditure in Germany would result in fewer imports from the rest of the world. These two factors would help restore balance of payments equilibrium without any need for changes in relative prices. Keynes, somewhat ironically, argued along more conventional lines by focusing on the terms of trade (Viner 1937, pp. 307-311). Viner, though placing far less importance on the role of 'relative demands' compared to Ohlin, accepted that - especially in the case of unilateral transfers such as reparations - these expenditure effects would play an equilibrating role:

It will conceded at once that, in the case, for instance, of the initiation of continuing unilateral remittances, the aggregate demand for commodities, in the sense of the amounts buyers are willing to purchase at the prevailing prices, will, in the absence of price changes, fall in the paying country and rise in the receiving country, and that unless there is an extreme and unusual distortion of the relative demands for different classes of commodities from their previous proportions this shift in demands will of itself contribute to an adjustment of the balance of payments to the remittances. (Viner 1937, pp. 293-294)

Viner was puzzled as to why this 'fairly obvious' point had not received prior recognition, yet he went on to describe how the classical writers - chastised by Ohlin for ignoring income

\footnotetext{
${ }^{5}$ Ohlin's explanation of the mechanism of adjustment also stressed that the price of domestic goods would rise relative to internationally traded goods in the receiving country. Viner probably would have argued that Ohlin's emphasis was mainly on income effects rather than relative price effects. In any case, it was Wilson's contribution that stimulated the development of the dependent economy model, not Ohlin's. A summary of Ohlin's argument can be found in Oppenheimer (1974).
} 
effects - had in fact made reference to similar themes in their writings, though relative prices were undoubtedly their primary focus. He provided examples from writers prior to Ohlin including Mill, Cairnes and Taussig - who had each made reference to income effects as a component in the mechanism of adjustment (Viner 1937, pp. 294-305). Indeed, Wilson had also assumed some portion of a capital inflow would fall on imports without relative price changes, but movements in prices were his primary focus. Viner, despite placing a greater emphasis on relative price effects (the terms of trade), now saw the mechanism of adjustment as being a combination of relative price and income/expenditure effects.

\section{Keynes's General Theory}

The emphasis on income effects received a huge boost after the publication of Keynes's The General Theory of Employment, Interest and Money (1936). In in his survey of international trade theory in the interwar years, Metzler (1948, pp. 211-213) explains how the classical price-specie-flow mechanism had an explicit acceptance of the quantity theory of money, which assumes that output is unaffected by monetary disturbances: gold flows from one country to another and the resulting increase (decrease) in the national money supply leads to higher (lower) price levels, not output. Keynes's book prompted doubt as to how the mechanism would operate in situations where prices were inflexible, yet it was not Keynes who advanced the income explanation of the mechanism. Metzler cites Robinson (1937) and Harrod (1939) as making the first contributions, with the mechanism of adjustment that grew out of Keynes's classic working as follows. Suppose imports increase in one country and this results in a balance of payments deficit in the importing country and a surplus in the exporting country. The higher export earnings lead to increased output and employment in the surplus country, which leads to further increases in expenditure and output. Part of this increased expenditure goes to imports, which offsets part, or perhaps all, of the balance of payments deficit (Metzler 1948, p. 215). This line of reasoning - which is familiar to any student of Keynesian economics - became known as the 'international trade multiplier'. Like the pricespecie-flow mechanism, it was seen more or less as being an automatic mechanism of adjustment. Though the Keynesian explanation was essentially identical to Ohlin's, Metzler argued that the international trade multiplier differed by offering an explanation of how far the income adjustment process would run. He noted that the view of most economists was that income effects would only partly restore balance of payments equilibrium after a shock; complete adjustment would also require a change in relative prices through the terms of trade, just as Viner had concluded (Metzler 1948, pp. 219-221). 


\section{The Elasticities Approach}

The continued emphasis on the terms of trade led to a refinement of the theory in the interwar years under the heading of 'exchange stability'. From Hume on, an implicit assumption of the terms of trade mechanism had been that an unfavourable movement in the terms of trade would necessarily lead to increased export earnings and reduced expenditure on imports. But definitive conclusions on these matters require knowledge of the relevant price elasticities. As a result, much research in the interwar years centred on the role played by four elasticities in a two-country model: the import elasticities of demand and the export elasticities of supply. The focus of this field was the stability of foreign exchange markets, since a balance of payments deficit implies an excess demand for foreign exchange. If the price of foreign exchange rose to clear this imbalance, there was the possibility that a balance of payments deficit could be worsened if import demand elasticities were sufficiently low (Metzler 1948, pp. 225-228). Thus the question revolved around the elasticity conditions required for exchange markets to be stable, a corollary being the conditions required for currency devaluation to improve the trade balance.

\section{BRM and Marshall-Lerner Conditions}

Two famous results in this field are the Bickerdike-Robinson-Metzler (BRM) condition and the Marshall-Lerner condition. The BRM condition is attributed to Bickerdike (1920), Robinson (1937) and Metzler (1948), though Metzler himself (1948, pp. 228-232) states that Bickerdike (1920), Robinson (1937) and Brown (1942) each discovered the condition independently. The BRM condition for exchange stability is shown below:

$$
K\left\{\frac{\eta_{1} \eta_{2}\left(1+e_{1}+e_{2}\right)+e_{1} e_{2}\left(\eta_{1}+\eta_{2}-1\right)}{\left(\eta_{1}+e_{2}\right)\left(\eta_{2}+e_{1}\right)}\right\}
$$

where $K$ is the proportional increase in the price of foreign exchange, $\eta_{1}$ and $\eta_{2}$ are the elasticities of demand for imports, and $e_{1}$ and $e_{2}$ are the elasticities of supply of exports. All elasticities are expressed in absolute value. For a devaluation to improve the trade balance, the expression in the brackets must be positive, which may not be the case if import demand elasticities are low. The BRM condition simplifies to the well-known Marshall-Lerner condition, attributed to Marshall (1923) and Lerner (1944), which assumes that export supply is perfectly elastic in both markets so that domestic currency prices of exports in each country remain unchanged. This assumption of constant domestic export prices means that a 
devaluation will always result in an unfavourable movement in the terms of trade, just as Taussig had argued. As $e_{1}$ and $e_{2}$ both approach infinity, it can be shown that a devaluation will improve the trade balance if the sum of import demand elasticities exceeds one. This is the Marshall-Lerner condition ${ }^{6}$ for effective devaluation.

\section{Relative Price and Income/Expenditure Effects}

Metzler's 1948 survey on international trade theory shows that there were two distinct explanations as to how balance of payments disequilibria were corrected. The traditional emphasis on the terms of trade remained, though it had now been enhanced through a focus on the relevant elasticities of demand and supply. Alongside the terms of trade was a separate mechanism which emphasised the role of income effects. This relatively new explanation emerged primarily as a result of the Keynesian revolution in macroeconomic theory. Although these two theories existed side by side, Corden (1965, p. 11) noted that they tended to be analysed in isolation. This analytical separation ended with James Meade.

\footnotetext{
${ }^{6}$ Metzler noted studies that suggested import demand elasticites were very low, but the belief was that over time imports would become more price elastic. The J-curve, which shows an initial deterioration in the trade balance before a subsequent improvement, was an outgrowth of the elasticities approach.
} 


\section{James Meade's The Balance of Payments}

\section{James Meade}

Born in England in $1907^{7}$, James Meade (1907-1995) studied classics for two years at Oxford before switching to economics at the newly created School of Philosophy, Politics and Economics. In 1930 he was elected to a Fellowship at Hertford College, Oxford, but spent a year at Cambridge where he, Richard Kahn, Piero Sraffa and Joan and Austin Robinson were members of the 'circus' that discussed Keynes's Treatise on Money (1930), providing a fertile intellectual background for Keynes's General Theory (see Meade 1977a). He returned to Oxford in 1931 and was Lecturer in Economics at Hertford College until late 1937, when he joined the Economic Section of the League of Nations in Geneva. Upon the outbreak of war, he returned to England in 1940 and became a member of the Economic Section of the War Cabinet, working closely with Keynes at the Treasury Department. In 1947 he began his tenyear tenure as Professor of Commerce (in the field of international economics) at the London School of Economics (LSE). It was during this period that he wrote his two-volume text, The Theory of International Economic Policy, consisting of The Balance of Payments (1951) and Trade and Welfare (1955). The work in these two books earned him - together with Bertil Ohlin - the Nobel Prize in Economics in 1977. Meade's focus eventually moved away from international economics, but concepts introduced in The Balance of Payments became central to the dependent economy model.

\section{The Balance of Payments Defined}

The definition of 'the balance of payments' used by Meade involves a distinction between 'autonomous' and 'accommodating' transactions (Meade 1951, Chapter I). Autonomous transactions can be thought of as those made by the private and public sector in the normal course of events; i.e., independent of any concern as to whether the balance of payments is in equilibrium. Accommodating transactions are those made by the monetary authority to ensure the balance of payments is in equilibrium. In the case of a balance of payments deficit, an accommodating transaction may be financed by running down foreign exchange reserves. Similarly, for a balance of payments surplus, the accommodating transaction is the accumulation of foreign exchange reserves. Thus 'the balance of payments' is the size of the accommodating transaction made to ensure balance of payments equilibrium.

\footnotetext{
${ }^{7}$ Biographical information on James Meade can be found in Arndt (1995), Corden (1996a, 1996b) and Meade (1977a).
} 


\section{The Model}

A static model consisting of two countries, A and B, is used almost throughout the book. All products in A and B can be traded internationally, and it is assumed that the prices of each country's products move up and down proportionately, thus allowing the products of each country to be treated as a single homogenous group. The relationship between the two countries is captured by the national income accounting identity:

Domestic expenditure less imports plus exports $=$ net national income

Domestic expenditure consists of consumption and investment expenditures (private and public) in a particular country, including imports. Hence imports, which lead to higher incomes for foreigners, must be deducted and exports added to reflect net national income. As the world consists of two countries, imports into country A are exports for country B, and imports into country B are exports for country A. As such, in equilibrium, the trade balance of one country is reflected in opposite sign in the other (Meade 1951, Chapter III).

\section{Disturbances and the Neutral Economy}

Meade uses this two-country, two-commodity framework to analyse the effects that 'disturbances' have on an initial and subsequent equilibrium. He distinguishes between three types of changes: spontaneous disturbances, policy changes in order to achieve some economic or social goal, and induced changes.

By a 'spontaneous disturbance' we shall mean any change in the underlying conditions, the cause of which we are prepared to take for granted and do not wish to examine, but the effect of which on the domestic and external position of our two countries we wish to examine. By a 'policy' change we shall mean a change which the State or some public authority brings about as a result of a definite decision of State policy in order to achieve some given end of general economic policy and in particular to offset some of the effects of a 'spontaneous disturbance'. Finally, by an 'induced' change is meant a change in some quantity which occurs on purely commercial principles because of the repercussions of some previous 'spontaneous' or 'policy' change. (Meade 1951, p. 43)

Spontaneous disturbances are exogenous changes that set off induced movements in other variables. These can be offset or supplemented by policy changes which themselves set off induced effects. Meade's analysis begins by considering the consequences of a spontaneous disturbance in 'the neutral economy', where fiscal policy, monetary policy, money wages, the 
exchange rate and commercial policy (e.g., tariffs, subsidies, etc.) are all held constant in both countries. Consider, then, a spontaneous increase in expenditure in country A (perhaps due to a lower savings rate) that takes place after an initial equilibrium in which both the trade balance and balance of payments are zero. A possible scenario would run as follows: the increased domestic expenditure in A boosts employment and income in A, which leads to additional domestic expenditure; part of the increased domestic expenditure is spent on imports, which boosts employment and income in B; the higher income in B leads to additional domestic expenditure and part of this falls on imports from A; and so on. The result is that income is higher in both countries and the trade balance has moved unfavourably for A and favourably for $B$. At the same time, because the increased domestic expenditure originated in A, prices in A are likely to rise more than prices in B; equivalently, the terms of trade are likely to move favourably for A and unfavourably for B. This change in relative prices brings into play the elasticity analysis of the previous section. Without referring to Marshall or Lerner by name, Meade employs their condition to evaluate relative price changes throughout the book and considers the sum of import demand elasticities greater than one to be the 'normal' case (Meade 1951, p. 75). The implication for the previous example is that the higher prices in A relative to B will result in a further deterioration in A's trade balance and an equivalent improvement in B's, creating further induced income effects once again. The upshot could be that the initial spontaneous disturbance results in a new equilibrium where, for example, national income is higher in both countries but the trade balance has moved unfavourably for A and favourably for B, resulting in a balance of payments deficit in A and surplus in B.

\section{Policy Targets}

As Corden (1965, p. 9-10) notes, previous writers on the adjustment mechanism would have been interested in the automatic processes that would restore balance of payments equilibrium over time. But the key themes in Meade's analysis emerge when such a spontaneous disturbance is not allowed to play out. Instead, the authorities in both countries use policy instruments in order to pursue two specific policy targets: internal and external balance. The policy targets of internal and external balance are the core focus throughout Meade's book, and the simultaneous preservation of internal and external balance is the objective of the authorities in both countries. Meade defines internal balance as follows: 
We shall talk as if the objective of internal balance were simply that of maintaining a level of total demand for all the country's products sufficiently high to maintain full employment, but not so high as to lead to a continuing inflation of money prices and costs. (Meade 1951, p. 106)

In short, internal balance is defined as full employment with stable prices ${ }^{8}$. External balance occurs when there is no deficit or surplus on the balance of payments; i.e., the level of accommodating finance is zero. This does not mean that the trade balance necessarily sums to zero: a negative trade balance could, for example, be offset by private capital inflow, requiring no accommodating transaction by the monetary authority. In our example, if both A and $\mathrm{B}$ were in internal and external balance to begin, the spontaneous increase in expenditure in A has resulted in above-full employment in both countries, a balance of payments deficit in A and a balance of payments surplus in B. These represent two of four possible disequilibrium situations, with situation (4) applying to country A and situation (2) applying to country B:

Any one country can be in any of four possible disequilibrium situations. It can be (1) a surplus country with a domestic slump, (2) a surplus country with a domestic boom, (3) a deficit country with a domestic slump, or (4) a deficit country with a domestic boom. (Meade 1951, p. 158)

\section{Policy Instruments}

The question that permeates Meade's book is how a country in any one of these disequilibrium situations can simultaneously restore internal and external balance. As the example showed, changes in expenditure and relative prices affect both the internal and external situations on their own. Higher (lower) domestic expenditure increases (reduces) employment and output at home but also leads to increased (reduced) imports. Likewise, an unfavourable (favourable) movement in the terms of trade - assuming the Marshall-Lerner condition holds - affects the external situation initially through higher (lower) exports and lower (higher) imports, which then influences the internal employment situation. Consequently, any spontaneous change that disrupts a situation of internal and external balance in both countries will require policy action to correct it. This is where policy instruments come into play. The policy instruments available to the authorities fit within two categories: ‘financial policy’ and 'price adjustments' (Meade 1951, Chapters VIII \& XI).

\footnotetext{
${ }^{8}$ Meade acknowledged in his Nobel acceptance speech that full employment and stable prices can be in conflict. He explained his definition of internal balance as a product of Keynesian thinking at the time, which saw stable prices as a characteristic of full employment (Meade 1977b).
} 
Financial policy consists of fiscal and monetary policy, and price adjustments refer to the manipulation of the exchange rate and/or money wages. The assumptions of 'the neutral economy' held these variables constant, but they can now be used by the authorities to pursue the twin policy objectives. This means that changes in government spending, taxation and interest rates can be used to influence domestic expenditure, and changes in money wages or the exchange rate - viewed as two means to the same end - can be used to alter the terms of trade.

\section{Conflicts Between Policy Targets}

A key point emphasised by Meade in chapters X and XI is that conflicts can arise between internal and external balance with the use of either policy instrument. Consider, for example, a country with a balance of payments deficit and a domestic slump. If the authorities use price adjustments to make their terms of trade less favourable, this improves the country's trade balance through higher exports and lower imports, which then boosts employment and income internally. Hence the price adjustment, whether through lower money wages or exchange depreciation, unambiguously helps to restore internal and external balance. But now consider an alternative response. Instead of price adjustments, this time the authorities use financial policy and increase government expenditure to combat unemployment. This helps restore internal balance, but the increased domestic expenditure leads to higher imports and this worsens the country's balance of payments problem. There is a conflict between targets with the use of financial policy in this situation. Meade shows with meticulous detail that each disequilibrium situation will involve a conflict between targets with one of the policy instruments. In doing so, he is making a critical general point: the number of policy objectives must be matched by the same number of policy instruments ${ }^{9}$. In the case above, if for some reason financial policy was the only instrument available to that country, the authorities would be forced to choose between internal and external balance.

\section{Two Instruments for Two Targets}

The key message is that two instruments are needed for two targets to avoid any conflict in policy. A valid question, then, is which instrument should be used in pursuit of each target. As price adjustments and financial policy both affect the internal and external situation, Meade explains that either instrument could be used to pursue either objective:

\footnotetext{
${ }^{9}$ Tinbergen (1952) made the same point at about the same time as Meade. A general mathematical exposition regarding the issue of policy targets and policy instruments can be found in Mundell (1968, pp. 207-210).
} 
Now there are two ways in which the authorities of a particular country may combine the use of financial policy and of price adjustment. (i) First, financial policy may be used for the preservation of internal balance and price adjustment for the preservation of external balance. (ii) Second, financial policy may be used for the preservation of external balance and price adjustment for the preservation of internal balance. On either of these principles the authorities of any one country can set about the simultaneous preservation of internal and external balance. (Meade 1951, p. 157)

Despite the effectiveness of both instruments, the assumption made for much of the book is, perhaps predictably, that financial policy is used to target internal balance and price adjustments are used to target external balance. This assumption can be used to demonstrate another critical message in Meade's analysis: in each of the possible disequilibrium situations, the necessary direction of one policy instrument is clear, but the necessary direction of the other is ambiguous. To illustrate this point, consider once more a situation in which a country has a domestic slump and balance of payments deficit. The restoration of internal and external balance would proceed as follows:

On principle i relative prices will be lowered in the interests of external balance and domestic expenditure will be inflated in the interests of internal balance. Internal balance will be very quickly restored although there is no net change in external balance. Relative prices must, therefore, continue to be lowered, which will tend now to produce a boom at home. The inflationary financial policy must, therefore, be replaced by a deflationary policy. In the end relative prices will be substantially lowered, while there may be a small net inflation or deflation of domestic expenditure by financial policy. (Meade 1951, p. 160)

In this particular disequilibrium scenario, the increased domestic expenditure and lower relative prices will both work to quickly address the internal slump, but they counteract each other on the external side. Therefore, relative prices must be lowered further to achieve external balance, but this leads to a domestic boom that will have to be corrected with a financial policy that reduces domestic expenditure. While it is clear that relative prices need to be lowered, the actual level of domestic expenditure at the simultaneous equilibrium is ambiguous: it could be higher or lower. This is just one example from the four disequilibrium situations. Meade shows with each one that the direction of only one instrument will be clear and the other ambiguous (Meade 1951, pp. 157-162). 


\section{Home-trade and Foreign-trade Products}

Though the core of Meade's analysis involves the maintenance of internal and external balance within his two-country, two-good model, he distinguishes between international ('foreign-trade') and domestic ('home-trade') goods in chapter XVIII. Foreign-trade products consist of exports and import-competing products and correspond to Wilson's definitions of exportables and importables. Meade begins chapter XVIII by considering the effects of a devaluation on the terms of trade and the trade balance, assuming that money wage rates are constant and both countries adopt financial policies for internal balance. He argues that the effect of devaluation is to raise the price of foreign trade products relative to home-trade products in the devaluing country. The prices of imports increase as a direct result of the devaluation, and import-competing products increase in price because consumers begin to favour them over imports. The higher prices for foreign-trade products relative to home-trade products leads to a movement of demand away from foreign-trade products toward hometrade products and a movement of supply away from home-trade products toward foreigntrade products. Meade identifies this as the mechanism that improves the trade balance in the devaluing country, and it echoes the reasoning employed by Wilson. As for the movement of the terms of trade after devaluation, Meade concludes that it is possible for the terms of trade to move favourably if in consumption and production there is low substitutability between export and non-export products. But if in either consumption or production substitutability is high, export and non-export prices will move proportionately and the products of a country can once again be treated as a homogeneous group. This is where the analysis of domestic goods ends. Having effectively assumed away a distinction between domestic and international goods, Meade then analyses the effects of a devaluation under different assumptions regarding the values of the import demand and export supply elasticities. That is, he considers the effects of a devaluation within the BRM framework.

\section{Sidney Alexander and Absorption}

Shortly after the publication of Meade's The Balance of Payments, Sidney Alexander (1952) also considered the effects of devaluation on the trade balance, though his focus was not on elasticities. Instead, his concern was the relationship between domestic expenditure and national income, both measured in real terms. He began, as Meade did, with the national income accounting identity, expressed below in its modern form:

$$
\mathrm{C}+\mathrm{I}+\mathrm{G}+(\mathrm{X}-\mathrm{M})=\mathrm{Y}
$$


Domestic expenditure, comprising private and public consumption and investment $(\mathrm{C}+\mathrm{I}+$ G), was called absorption. Alexander noted that the trade balance equals the difference between real income and real absorption: when real absorption is less than real income, the trade balance is positive; when real absorption exceeds real income, the trade balance is negative. A currency devaluation, then, can only improve the trade balance to the extent that the level of real income rises relative to the level of real absorption.

Whether this would occur depended on the internal position of the economy. In situations of unemployment, Alexander argued along similar lines to Meade: the devaluation would lead to an increase in exports and a reduction in imports, which would have the effect of putting idle resources to work and boosting real income. As long as the increase in real income exceeds the increase in real absorption, which he considered likely, then the devaluation would improve the trade balance. In situations of full employment, however, the consequences of a devaluation differ. Since full employment means the economy is at maximum real income, a devaluation would only lead to higher prices and higher money income. Thus, with real income constant, devaluation improves the trade balance only if it leads to a reduction in real absorption. Alexander identified a number of ways devaluation could directly lower the level of absorption, such as cash balance effects and income redistribution effects, but judged their effect on real absorption to be weak at times of full employment (Alexander 1952, p. 274). Therefore, if devaluation cannot change real income or real absorption, then it cannot affect the trade balance.

This was a critical insight that Meade had overlooked. As Corden (1965, pp. 14-15) and Krueger (1969, p. 7) pointed out, Meade had always assumed that internal balance would be maintained by appropriate financial policy; he did not consider a situation where a country began in internal balance and the effects of a devaluation were allowed to play out. Alexander's contribution was critical not only because he highlighted situations in which devaluations were ineffective (that had already been argued with the elasticity approach) but also because he demonstrated the critical link between real absorption and the balance of payments at full employment. In situations of full employment, devaluation can only improve the trade balance if it is accompanied by policies to reduce real absorption. Using Meade's terminology, the critical instrument for correcting a balance of payments deficit in a situation of internal balance is financial policy, not price adjustments (Corden 1965, p. 16). 


\section{Trevor Swan and James Meade}

\section{Trevor Swan}

The works of Meade in particular and Alexander were to become central to Trevor Swan's contribution. Born in Sydney in $1918^{10}$, Swan studied economics at the University of Sydney and graduated with first-class honours and the University Medal in 1940. After teaching briefly at the University of Sydney, he joined the Department of War Organisation of Industry as an economist in 1942 and was prominent in the writing of the White Paper Full Employment in Australia (1945). In 1946 he became chief economist in the Department of Post-War Reconstruction, and in 1947-48 he was seconded to the British Cabinet Offices, where he had the opportunity to interact with leading British economists - including James Meade, whom he found most impressive (Butlin \& Gregory 1989, p. 371). In 1950, aged only 32, he was appointed Foundation Chair in Economics at the newly created Australian National University (ANU). Swan's appointment was the culmination of an intriguing worldwide search that involved unsuccessful approaches to, among others, James Meade, Paul Samuelson and Roland Wilson (Cornish 2007a). Swan remained at the ANU until his retirement in 1983. In 1975 he commenced the first of two five-year terms on the board of the Reserve Bank of Australia. In 1987 he received, jointly with Colin Clark, the inaugural Distinguished Fellow Award from the Economics Society of Australia. He died in Canberra in 1989.

\section{Australia in the 1950s}

The Australian economic situation in the 1950s provided the ideal practical application of the new contributions of Meade and Alexander. With the devastation of the Depression still fresh in the nation's consciousness, full employment became a bipartisan policy objective of the Australian Parliament. The impetus for this commitment was the 1945 White Paper on full employment, which explicitly acknowledged the role to be played by the Australian Federal Government in maintaining aggregate demand at a level necessary for high and stable employment (see Coombs 1994). On this measure alone, the policy was a success: unemployment was remarkably low in the 1950s, averaging only 0.99 per cent during the decade (Reserve Bank of Australia 1997). However, these low levels of unemployment coincided, perhaps predictably, with balance of payments problems. Corden (1968, p. 98)

\footnotetext{
${ }^{10}$ Biographical information on Trevor Swan can be found in Butlin and Gregory (1989), Cornish (2012), King (2007), and Swan (2006).
} 
explains how the Korean War (1950-1953) led to an export boom that caused an internal boom. Both preceded a balance of payments crisis caused by a slump in wool prices, high wages, and high levels of public and private investment. In 1952 the government responded by introducing wide-ranging import restrictions, and these remained in place until 1960. Thus Australia in the early-mid 1950s was, in Meade’s terms, a country experiencing a domestic boom and balance of payments deficit. This, of course, was precisely the full employment situation that Alexander applied his absorption approach to.

\section{Two Papers for Two Conferences}

It was within this context that Trevor Swan made his contribution. His two articles were presented at seminars in 1953 and 1955, though both were published years later in 1960 and 1963 respectively. His first paper, titled ‘Economic Control in a Dependent Economy’, was an algebraic formulation of Meade's ideas, particularly around the notions of policy targets and policy instruments, yet it differed from Meade's approach in its treatment of the terms of trade. His second paper, titled 'Longer-Run Problems of the Balance of Payments', built on the key themes of the first but was more specific in its application to the Australian situation of the 1950s. Furthermore, the influence of Meade and Alexander was more pronounced in that paper.

\section{'Economic Control in a Dependent Economy'}

Swan's first paper, presented at an ANU seminar in 1953, explored the most effective way policy instruments could be manipulated by Australian authorities to achieve three policy targets: internal balance, external balance and price stability. He introduced an algebraic model with six variables: real income $(Y)$, the real import surplus $(J)$, real expenditure $(D)$, the internal price level $(P)$, the external price level $(R)$, and the money wage level $(W)$. The external price level is an index of export and import prices measured in domestic currency. The three policy targets - internal balance, external balance, and price stability - require specific values of $Y, J$ and $P$ to be achieved simultaneously. These target variables can be controlled by manipulating real expenditure (financial policy), money wages (price adjustments through income policy), and the external price level (price adjustments through the exchange rate). Thus far, aside from the addition of an extra target and the emphasis on real variables, the analysis was essentially no different to Meade's. However, Swan departed from Meade in one crucial respect when listing the model's assumptions: 
We take as given the available labour force and other domestic resources, and the technical and entrepreneurial environment which determines the productivity and competitive structure of the economy ... Similarly, we take as given the terms of trade between export and import prices, and also the level of capital inflow or outflow and other financial transfers. This means that the balance of payments is fully determined at any volume by the import surplus. To treat the terms of trade as a datum is in sharp contrast with most of the literature; the argument is directly applicable to a "dependent economy" - i.e., a small country which trades in world markets that are competitive in the sense that the prices it receives for exports and pays for imports are independent of its domestic conditions of supply and demand. However, for a majority of countries (by number, not by weight), and typically for those exporting chiefly primary products, this assumption is closer to reality than the usual text-book situation in which the terms of trade are regarded as sensitive to domestic changes, and home-trade products are more or less interchangeable with exports ${ }^{1}$.

1. This is, for example, the situation envisaged almost throughout the latest standard work, J.E. Meade's The Balance of Payments, 1951. Thus Meade insists that the whole modus operandi of exchange depreciation as a means of improving the balance of trade is by cheapening exports in terms of imports (e.g. p. 170). Again, he reaches the conclusion that an effective exchange depreciation must reduce real wages via a worsening of the terms of trade (p. 202), although in fact the conclusion holds even if the terms of trade are left unchanged. It is significant that an economist from a primary producing country was one of the first to develop balance of payments theory along new lines by stressing the relationship between external prices and domestic costs, rather than the terms of trade (Dr. Roland Wilson, Capital Imports and the Terms of Trade, 1930). (Swan 1960, pp. 53-54)

Swan employed the argument raised by Wilson two decades earlier, though he made it more forcefully. A small or 'dependent' economy such as Australia is a price taker in world export and import markets. This means the prices of its exports and imports are determined in world markets and cannot be influenced by domestic conditions of supply and demand. Swan appreciated how significant a departure this was from conventional thought; he referenced Meade but also could have listed Viner and Taussig before him. Meade, whose basic framework treated a country's goods as a single homogeneous group, had always assumed that a depreciation or reduction in money wages would lead to an unfavourable movement in the terms of trade. He discussed the possibility of the terms of trade moving in either direction in his brief treatment of home-trade and foreign-trade products, but even then he assumed a depreciation would affect the terms of trade in some way. In effect, then, Meade had never considered the case of a small country whose terms of trade are determined exogenously. In 
making his point, Swan was again challenging the orthodox view which saw the terms of trade as the key relative price in balance of payments adjustment. He altered Meade's analysis by emphasising the price of international goods relative to domestic money wages (Wilson's relative price expressed in terms of work hours rather than commodity units) instead of the terms of trade. A devaluation cannot influence the terms of trade of a small country, but it raises the price of international goods (exportables and importables) relative to domestic money wages. This in turn instigates demand and supply side responses that lead to an improved trade balance.

With the emphasis switched from the terms of trade to the ratio of the external price level $(R)$ to domestic money wages $(W)$, Swan's model thus had the following functional relationships:

$$
\begin{aligned}
& D=Y+J \\
& Y=f\left(D, \frac{R}{W}\right) \\
& J=f\left(D, \frac{R}{W}\right) \\
& P=f(D, R, W)
\end{aligned}
$$

Equation (4) is a rearranged statement of the national income identity; equations (5) and (6) show that the internal position $(Y)$ and external position $(J)$ both depend on real expenditure and the international-domestic price ratio, i.e., income and relative price effects; and equation (7) states that the internal price level depends on real expenditure, external prices and money wages. The three targets of internal balance, external balance and price stability each require specific levels of $Y, J$ and $P$. This means there must be one value of $D$ and one value of $R / W$ that guarantees internal and external balance simultaneously. Price stability then depends on the values of $R$ and $W$, holding the ratio between the two variables constant (Swan 1960, p. 56). As higher levels of $D$ and higher levels of $R / W$ both lead to increased real output, maintaining a constant level of real output (internal balance) requires that these variables move in opposite directions. Analogously, as higher levels of $D$ and lower levels of $R / W$ both lead to higher imports, maintaining a constant import surplus (external balance) requires that these variables move in the same direction. With real income, the real import surplus and the internal price level as targets of economic policy, Swan, like Meade, explained the various 
ways in which a policy instrument could be associated with a particular policy target. He concluded that the most effective regime for simultaneous equilibrium would see the Treasury control the level of real expenditure to target internal balance, the Arbitration Court control the level of money wages to target external balance, and the Commonwealth Bank (the Australian central bank at the time) control the exchange rate to target internal price stability (Swan 1960, pp. 65-66).

\section{'Longer Run Problems of the Balance of Payments'}

Swan presented his second paper at the ANZAAS conference in Melbourne in 1955. He began by lamenting the lack of emphasis in the 1945 White Paper given to the influence of real expenditure and relative prices on the balance of payments:

Fears about the future, which are shared by many economists, arise from a suspicion that in all these three directions the will and/or the means to the required policy action are lacking, and that we are therefore faced with a persistent tendency towards over-spending, excessive wage costs, balance of payments deficits, and more or less permanent import restrictions with a consequent bias towards inflation and a "distortion" (in some senses) of patterns of investment and production. (Swan 1963a, p. 385)

The emphasis on real expenditure and relative prices was indicative of the theoretical work by Meade and Alexander that followed the White Paper's publication. Swan went on to convey his point diagrammatically, using for the first time an illustration which has since become known as the 'Swan diagram'. He dropped the target of price stability from his previous seminar and focused instead on internal and external balance. All other assumptions from the previous seminar - such as constant terms of trade, capital flows and productivity - remained. The diagram, shown in figure 2, was presented with the international price level relative to money wages - renamed the 'cost ratio' - on the vertical axis and the level of real expenditure on the horizontal axis. He described how internal balance could be maintained with a high cost ratio (a more competitive international position) as long as real expenditure is kept low, and vice versa. Analogously, external balance can be maintained with a high cost ratio as long as real expenditure is also high, and vice versa (Swan 1963a, p. 386). At their intersection, the two lines identify the specific values of real expenditure and the cost ratio needed to simultaneously achieve internal and external balance. 


\section{Figure 2: The Swan Diagram}

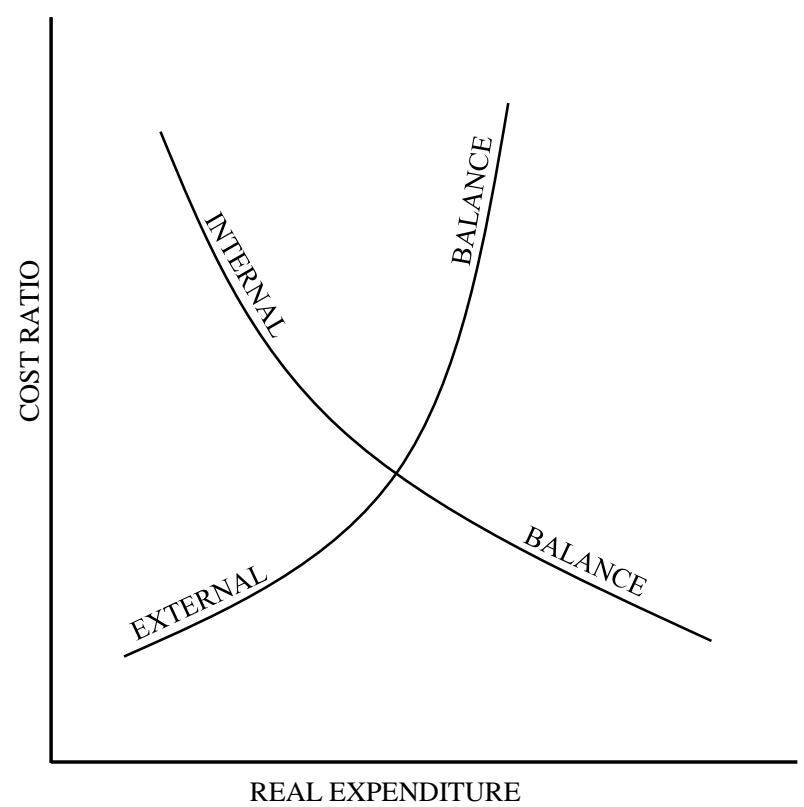

\section{Meade’s Situations Become Swan’s Zones}

Meade's contribution is essential to the interpretation of the Swan diagram. As the internal balance line shows all real expenditure and cost ratio combinations that result in full employment, holding the cost ratio constant and reducing real expenditure (a horizontal movement to the left) results in unemployment. Similarly, holding the cost ratio constant and increasing real expenditure (a horizontal movement to the right) leads to over-full employment. The same logic applies to external balance. Holding the cost ratio constant and reducing real expenditure decreases imports and creates a balance of payments surplus, whereas an increase in real expenditure increases imports and creates a balance of payments deficit. Therefore, every point to the left of the internal balance line represents unemployment and every point to the right represents over-full employment. Similarly, every point to the left of the external balance line represents a balance of payments surplus and every point to the right represents a balance of payments deficit. The external and internal balance lines divide the diagram into Swan's 'four zones of economic unhappiness'. These zones, which are identified in figure 3, are precisely the four disequilibrium scenarios described in Meade's The Balance of Payments. Restoring internal and external balance within any zone requires a combination of cost ratio (relative price) and real expenditure adjustments. 
Figure 3: Swan's Four Zones of Economic Unhappiness

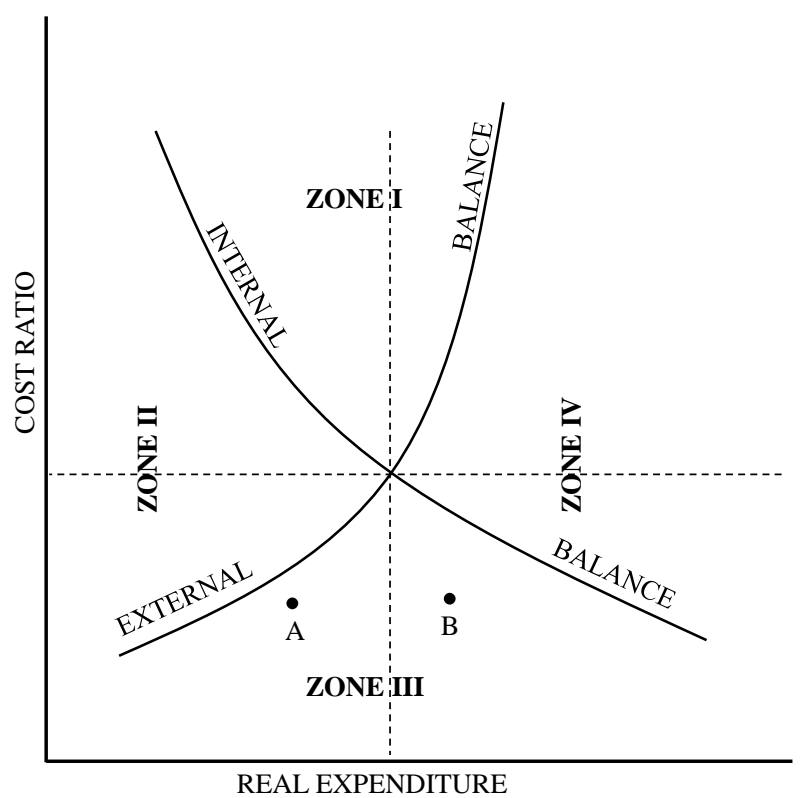

Zone I: Over-full employment and

balance of payments surplus.

Zone II: Under-full employment and

balance of payments surplus.

Zone III: Under-full employment

and balance of payments deficit.

Zone IV: Over-full employment and

balance of payments deficit.

\section{Policy Conflicts and Ambiguities}

The Swan diagram also conveys Meade’s findings about conflicts between targets when only one instrument is available, and uncertainty as to the necessary direction of one policy instrument in each disequilibrium situation (zone). The conflict can be seen by considering point $\mathrm{A}$ in figure 3 , which shows a situation of unemployment and balance of payments deficit (zone III). If, for example, the control of real expenditure was the only instrument available, then a choice must be made between reducing real expenditure and moving toward external balance, or increasing real expenditure and moving toward internal balance. The same argument can be made if only relative price adjustments are available, thus emphasising the need for two policy instruments for two policy targets. On the issue of ambiguity for one policy instrument in each zone, Swan elucidated Meade’s point:

Between the two halves of each zone, as divided by the broken straight lines, the causes of disequilibrium differ. Only in Zones II and IV is the level of spending unequivocally too low or too high; only in Zones I and III are costs unequivocally too low or too high. Thus in each zone the necessary direction of adjustment of one of the two factors, E (real expenditure) and R (cost ratio), is apparent, whereas the other may be either too high or too low, depending on our precise position in the zone. Conversely, over-spending is consistent with both unemployment and over-employment, and with both a balance of payments surplus and a deficit (but not with under-employment and a 
surplus together); and so on. This is the source of many of the problems and errors of economic policy - if one factor is substantially out of line, the "natural" indications for the other may be quite misleading. For policy, we need to know which quadrant we are in, whereas the mere facts of the employment situation and the balance of payments can tell us only which zone we are in. (Swan 1963a, p. 387)

This is largely a restatement of Meade's point, but the diagrammatic exposition adds clarity. Consider, again, point $\mathrm{A}$ in zone III. The diagram shows that a return to internal and external balance will ultimately require both an increase in real expenditure and an increase in the cost ratio. Now contrast that solution with point $B$, which is also in zone III. In this case, simultaneous internal and external balance requires a decrease in real expenditure and an increase in the cost ratio. Meade's point is confirmed: in each zone the necessary direction of one instrument is clear but the other is ambiguous. Swan clarified Meade's analysis by pointing out that economic data can only tell us which zone we are in, whereas an appropriate policy response requires knowledge of which quadrant we are in. Consequently, a 'natural' policy response - such as increased expenditure at point B - may be counterproductive.

\section{Absorption in the Swan Diagram}

The key insight of Alexander's absorption approach can also be seen in the Swan diagram. Any point on the internal balance line to the right of the external balance line is a situation of full employment and balance of payments deficit. A depreciation, which increases the external price level, is a vertical movement away from the internal balance line. If, as Alexander assumed, the full employment level of output cannot be exceeded, then the increase in the cost ratio must be accompanied by a reduction in real expenditure that takes the position of the economy back onto the internal balance line. Therefore, real expenditure must fall if a depreciation is to restore external balance at full employment.

\section{James Meade Visits Australia}

The year after Trevor Swan first presented his diagram, he had the opportunity to discuss his amendment to Meade's model with the author himself. A joint initiative between the Commonwealth Bank and the economics department at the ANU saw Meade visit Australia as a guest in 1956 (Arndt 1995). He was stationed at Swan's department for the duration of his visit and published two articles in the Economic Record during his stay. The first, titled 'The Price Mechanism and the Australian Balance of Payments' (1956), dealt with the Australian internal and external situation of the time. Meade advocated a deflationary 
financial policy to contain domestic expenditure and reduce over-employment, but he felt this particular policy would not be enough to correct the balance of payments situation (once again, one instrument was insufficient). As a result, he advocated a flexible exchange rate regime (in place of import restrictions) as a long-term solution to Australia's 'residual' balance of payments problem. Although this was Meade's textbook solution to a problem of over-employment and balance of payments deficit, there was change in emphasis regarding the effects of devaluation. No longer did a devaluation operate through the terms of trade; instead, the effect was to raise the price of exports and imports relative to domestic goods. Meade had accepted Swan's argument that the terms of trade is effectively fixed for countries like Australia:

Now a depreciation of the exchange rate and a cut in wage-rates are best regarded as alternative means of raising the price of imports and exports relatively to the price of other products in the Australian economy. (Meade 1956, p. 244)

Australia's terms of trade are not likely to be seriously affected by a general price adjustment. The price in foreign exchange of her imports is not likely to change much because of the high elasticity of supply of these products to her. The price of her exports in foreign exchange is not likely to be affected very significantly because the elasticity of her supply of exports to the outside world is likely to be rather low in the case of those products for which the overseas elasticity of demand is low. The Australian economy is such that a general adjustment of Australian prices and costs relatively to world prices and costs would effectively improve Australia's balance of trade. It would considerably decrease her demand for imports and somewhat increase her supply of exports at not very different terms of trade between imports and exports. (Meade 1956, p. 248)

Meade had clearly been influenced by Swan. He now accepted that the crucial relative price was the price of international goods (exports and imports) to domestic goods. He argued that his preferred option of currency devaluation would improve the balance of payments in two ways: first, higher domestic prices for exportables would encourage more production in those sectors and also cause demand to shift from exportables to domestic goods; second, higher domestic prices for importables would encourage more production in those sectors and also cause demand to shift from importables to domestic goods. These effects would bring about an increase in exports and a reduction in imports (Meade 1956, pp. 245-246). Meade had briefly discussed this mechanism in his chapter on domestic goods but never in the context of constant terms of trade. 


\section{The Models of Salter and Corden}

\section{Wilfred Salter}

The year of James Meade’s visit coincided with Wilfred Salter's appointment by Trevor Swan as a research fellow in the ANU's Research School of Social Sciences. Born in Perth in $1929^{11}$, Salter studied economics at the University of Western Australia (UWA) and graduated with first-class honours in 1953. He then moved to Cambridge University on a Hackett Travelling Scholarship, where he was awarded his $\mathrm{PhD}$ in 1955. His $\mathrm{PhD}$ thesis formed the foundation of his book Productivity and Technical Change (1966), which Harcourt (2007, p. 243) describes as 'a modern classic in economics'. He left Cambridge for John Hopkins University in 1955, holding the position of research fellow for the 1955-56 academic year. He joined Swan at the ANU in September 1956 and remained there until he was hired as an Assistant Secretary in the Cabinet Division of the Prime Minister's Department in 1960. In 1962 he joined Harvard University’s advisory development service, moving to Pakistan as an economic adviser to the government. He remained in Pakistan until his premature death from heart disease in 1963.

\section{The Composite Commodity Theorem}

Salter's contribution to the dependent economy model, published as 'Internal and External Balance: The Role of Price and Expenditure Effects' in the Economic Record in 1959, was completed during his tenure in Swan's department at the ANU. What is striking about Salter's contribution is how much of a deviation it was from his prior research. His honours thesis at UWA involved the construction of an index of industrial production; his $\mathrm{PhD}$ thesis, which evolved into his classic book, concerned technical change and productivity; and his other published article at the ANU considered the aggregation of the capital stock. This prior research, though seemingly disparate, may offer a clue as to why Salter took an interest in Swan's model. Weber (2011, p. 111) describes how Salter gained an understanding of the composite commodity theorem during his honours research at UWA. The theorem, attributed to Leontief (1936) and Hicks (1946), states that groups of commodities can be aggregated into a single commodity in economic policy analysis as long as their relative prices remain unchanged. Weber (2011) explains that issues of aggregation were a common thread throughout Salter's research. Salter recognised that the capital stock is an invalid economic

\footnotetext{
${ }^{11}$ Biographical information on Wilfred Salter can be found in Cornish (2004), Dowsett and Peters (1964), Harcourt (1962, 2007), Pitchford (2002), and Swan (1963b).
} 
aggregate in macroeconomic modelling because macroeconomic policy affects the term structure of interest rates and hence relative prices between capital goods of different longevity. But since domestic economic policy does not affect the terms of trade of a small country, he realised that exportables and importables could be aggregated into a composite commodity.

\section{The Salter Model}

Salter begins his article by restating the small country assumption and notes the 'considerable simplifications' that this assumption allows; namely, the subsequent aggregation of exportables and importables into the composite commodity, traded goods.

The procedure of treating exportables and importables as a single class of good (traded goods) is quite legitimate so long as the terms of trade are unaffected by events inside Australia ${ }^{4}$. The reason is that any quantity of exportables may be exchanged for importables at the relative price determined by the given terms of trade.

4. The formal assumption is a perfectly elastic world demand for exports, and a perfectly elastic world supply of imports. (Salter 1959, pp. 226-227)

Salter, without explicitly referring to the composite commodity theorem, understood that the aggregation of exportables and importables is acceptable in economic policy analysis because of the constant terms of trade assumption. This enabled him to reduce Swan's three-good model down to two, bringing it into line with traditional two-dimensional international trade geometry (Corden 1968, p. 104). The Salter model is shown in figure 4, with the quantity of non-traded goods on the vertical axis and the quantity of traded goods on the horizontal axis. With only two goods in the model, there is only one relative price: the price of traded goods (international) relative to non-traded goods (domestic). 
Figure 4: The Salter Model

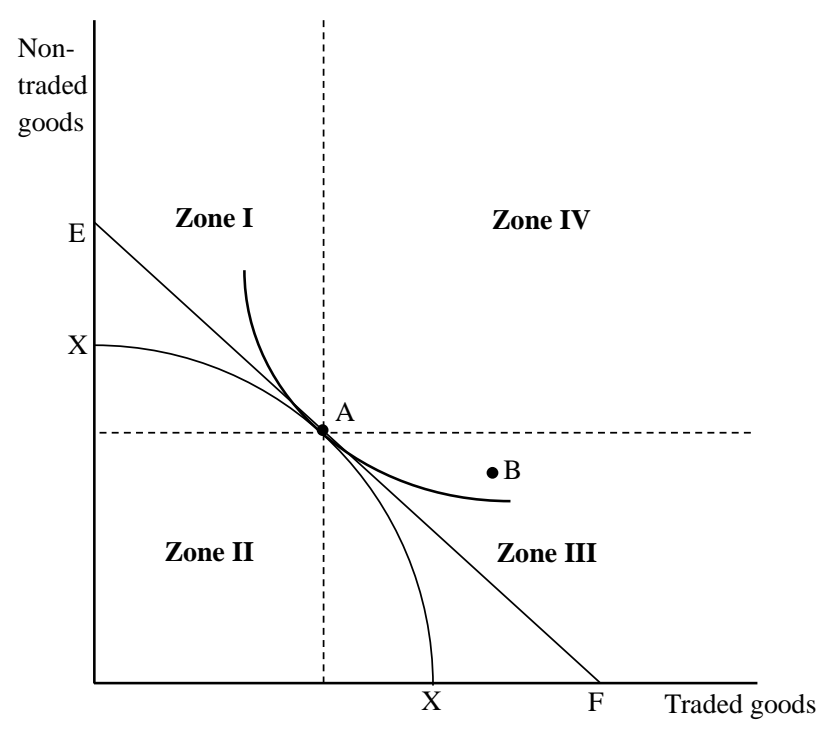

The production possibility frontier XX shows all the combinations of non-traded and traded goods that can be produced with full employment of the economy's resources. The expenditure line EF represents the level of domestic expenditure (absorption). As drawn, domestic expenditure is exactly equal to full employment income, though expenditure and income need not coincide. The slope of the expenditure line is given by the price of traded goods relative to non-traded goods. The economy's production point occurs at the point of tangency between the full employment income line EF and the production possibility frontier. The consumption point occurs at the highest possible indifference curve given the level of domestic expenditure.

\section{Internal and External Balance}

Salter used his diagram to illustrate some of the core ideas in Meade's and Swan's prior work. In figure 4, the consumption and production points of the economy lie in exactly the same position at point A. As a result, the demand for non-traded goods is equal to the production of non-traded goods and the demand for traded goods is equal to the production of traded goods. This is a situation of internal and external balance within the Salter model ${ }^{12}$. The location of the consumption point relative to the production point determines which of Swan's zones the economy is operating in. Assuming that production is at point A, if the consumption point is

\footnotetext{
${ }^{12}$ Salter, like Swan, assumed that the balance of payments is fully determined by the trade balance, i.e., the demand for versus the supply of traded goods. Therefore, other balance of payments items such as capital flows are assumed constant.
} 
anywhere other than A then the economy must be in one of Swan's four zones of economic unhappiness. For example, point $B$, which is southeast of $A$, is our familiar situation of unemployment and balance of payments deficit (zone III). At B, the demand for non-traded goods falls short of supply and the demand for traded goods exceeds the domestic supply.

\section{Price and Expenditure Effects}

As Meade argued in The Balance of Payments, the correction of any disequilibrium situation requires a combination of financial policy and price adjustments. In Salter's model, the effect of a change in financial policy (e.g., change in government spending) is shown by a parallel shift of the expenditure line EF. Higher government spending increases domestic expenditure and shifts the expenditure line outward; lower government spending moves it inward. Price adjustments affect the price of traded goods relative to non-traded goods and are reflected by a change in the slope of the income and expenditure lines. The diagrammatic representation of these price adjustments is where Salter's model stood out from previous contributions. Wilson, Swan and Meade had all described in words the consumption and production responses to a change in the relative price, but Salter's two-dimensional diagram made graphical illustration possible. A depreciation, by increasing the price of traded goods relative to non-traded goods, steepens the income and expenditure lines. This creates a new point of tangency on the production and consumption side, both of which influence the internal and external situation. Figure 5 shows the possible effect of a depreciation that follows an initial position of internal and external balance at point $A$. The new relative price causes the production point to shift to B (an increase in the production of traded goods and a decrease in the production of non-traded goods) and the consumption point to shift to C (a decrease in the consumption of traded goods and an increase in the consumption of non-traded goods). The consumption and production responses combine to create an excess supply of traded goods (a trade surplus), shown as the horizontal distance between B and C. 


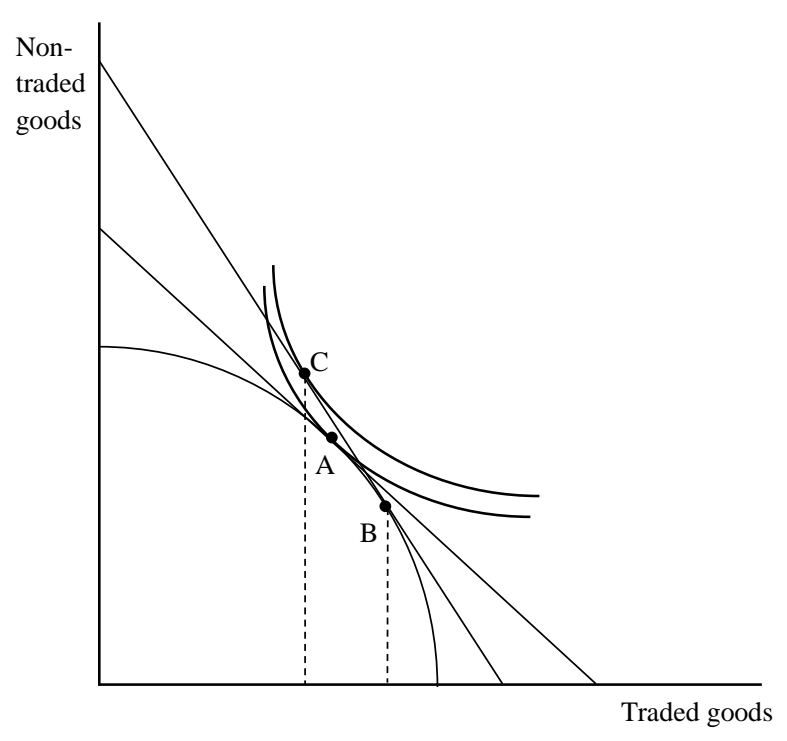

\section{Max Corden}

Around the time the dependent economy model was being discussed and developed at the ANU, Max Corden (1927-) $)^{13}$ was appointed Lecturer in Economics at the University of Melbourne in 1958. Corden had studied commerce in his undergraduate days there, graduating with first-class honours in 1950. He moved to the London School of Economics in 1953 and was awarded his PhD (supervised by James Meade) in 1956. His proximity to Meade - both as supervisor and coursework teacher - meant that he was very familiar with the ideas developed in The Balance of Payments (Corden 1996a). It is unsurprising, then, that the ideas being developed at the ANU, which were an outgrowth of Meade's seminal text, were to be of interest to him. Corden's contribution, published as 'The Geometric Representation of Policies to Attain Internal and External Balance' in The Review of Economic Studies in 1960, incorporated the ideas of Meade, Swan and Salter, but distinguished itself from Swan and Salter by including a larger emphasis on issues such as import restrictions and tariffs - policies that were relevant to the Australian economic situation at the time. Furthermore, the influence of Harry G. Johnson's ‘Towards a General Theory of the Balance of Payments' (1958) was clear.

\footnotetext{
${ }^{13}$ Biographical information on Max Corden can be found in Coleman (2006), Corden (2000) and Groenewegen and McFarlane (1990).
} 


\section{Expenditure Switching and Expenditure Reducing/Changing Policies}

Johnson's (1958, pp. 153-168) discussion of balance of payments theory includes a prominent focus on the absorption approach. Like Alexander before him, he explains how a trade deficit implies an excess of real absorption over real income/output. He distinguishes between two polices that can improve the balance of payments: those that aim at increasing real output and those that aim at reducing real absorption. Since domestic output depends on the amount of demand for it, an increase in output requires that expenditure (either foreign or domestic) be switched onto domestic output. Johnson classifies expenditure-switching policies as either 'general' or 'selective'. General policies consist of devaluation and deflation, whereas selective policies consist of trade controls such as import restrictions and tariffs. Policies that aim at directly reducing real absorption are expenditure-reducing policies. Using Johnson's terminology, Meade's price adjustments and financial policies are types of expenditureswitching and expenditure-changing policies respectively. As Alexander had shown with depreciation, Johnson explains that an expenditure-switching policy alone is futile in situations of full employment unless it is accompanied with expenditure reduction by way of fiscal or monetary policy. The switching policy would then offset the employment reducing effects of the reduced expenditure (Johnson 1958, p. 167).

\section{Corden’s Model}

Corden's article was at its core a diagrammatical analysis of expenditure-switching and expenditure-changing policies. The basic model, which was originally used in Hemming and Corden (1958) and is shown in figure 6, has home-produced goods (non-traded) on the vertical axis and imports (rather than traded goods) on the horizontal axis. The relative price that determines the slope of the expenditure line is thus the price of imports in terms of homeproduced goods. The foreign currency prices of imports and exports are assumed constant, as is the volume of exports. Though the relative price in Corden's model differs from Salter's, the constant terms of trade assumption means that any change in the price of imports relative to home goods is a proportionally equivalent change in the price of traded goods relative to non-traded goods. The assumption that the foreign currency value of exports does not change, together with the assumption that all other balance of payments items are fixed (e.g., capital flows), means the balance of payments is fully determined by the level of imports consumed. Likewise, the internal situation is determined by the consumption level of home-produced goods. 


\section{Figure 6: The Corden Model}

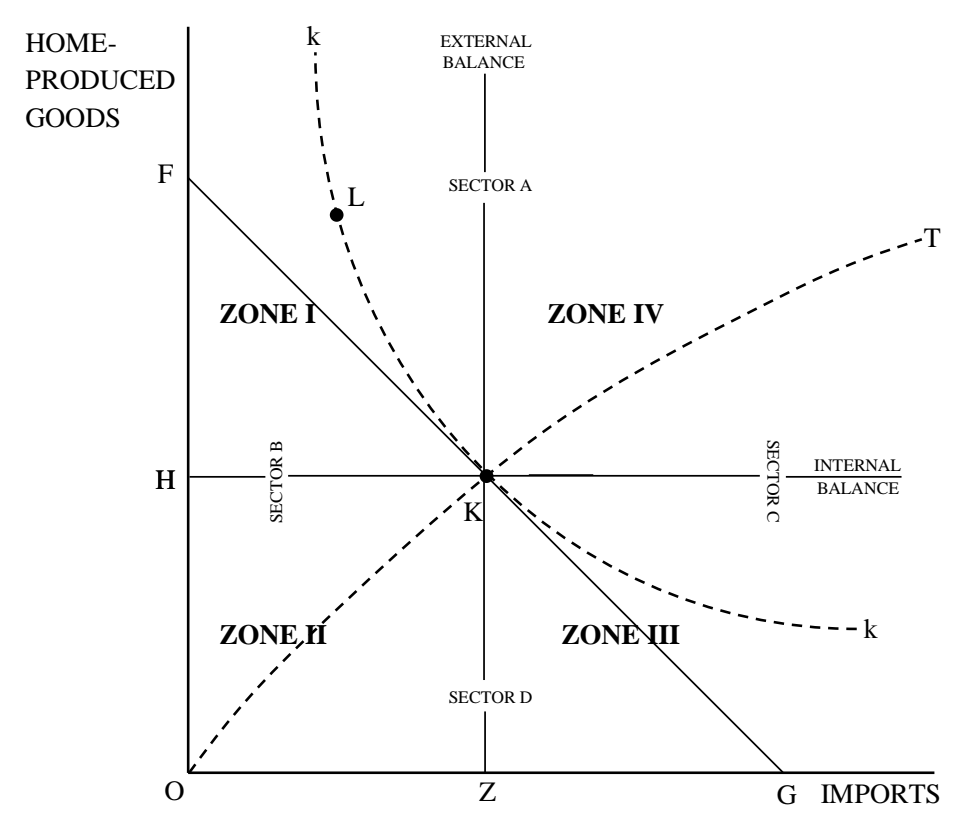

\section{Internal and External Balance}

The solid horizontal and vertical lines emanating from $\mathrm{H}$ and $\mathrm{Z}$ in figure 6 indicate the consumption levels of home-produced goods and imports necessary for internal and external balance. Simultaneous equilibrium requires the consumption point of the economy to lie at the intersection of these two lines at point K. As in the Salter model, the point of tangency between the indifference curve and the expenditure line determines the consumption point (not to be confused with the overall equilibrium point) of the economy. Since tangency between the indifference curve kk and the expenditure line FG in figure 6 occurs at point K, this is a situation of internal and external balance. Disequilibrium situations occur if the consumption point is anywhere other than $\mathrm{K}$. Consumption points to the right of $\mathrm{K}$ are situations of balance of payments deficit, and consumption points to the left of $\mathrm{K}$ are situations of balance of payments surplus. Similarly, consumption points above K indicate overemployment, and consumption points below $\mathrm{K}$ indicate underemployment. These lines then divide the Corden model into Swan's four zones of economic unhappiness in the same manner as the Salter model. Correcting a disequilibrium situation then requires a combination of expenditure-switching and expenditure-changing policies to avoid conflicts between targets. 


\section{Swan's Quadrants Become Policy Sectors}

As in the Swan diagram, simultaneous equilibrium requires a specific relative price (shown by the slope of the expenditure line FG) and a specific level of real expenditure (shown by the indifference curve ${ }^{14} \mathrm{kk}$ ). The dashed OT line is the income consumption curve for the relative price that prevails at the simultaneous equilibrium. Corden uses the indifference curve kk and the income consumption curve OT to divide the diagram into 'policy sectors', which are analogous to Swan's quadrants. As the indifference curve is used to indicate constant levels of real expenditure, any consumption point north-east of kk (on a higher indifference curve) means real expenditure is higher than the level needed for internal and external balance; similarly, any consumption point south-west of kk means real expenditure is lower than the level needed for internal and external balance. Consumption positions north-west and southeast of the OT line indicate the necessary direction for the relative price. If the consumption point is north-west of the OT line, it must mean the price of imports relative to homeproduced goods is higher than the level needed for internal and external balance; similarly, if the consumption point is south-east of the OT line, it must mean the price of imports relative to home-produced goods is lower than the level needed for internal and external balance. To understand this point, consider consumption point $\mathrm{L}$ on the indifference curve kk. Real expenditure at $\mathrm{L}$ is equal to the level necessary for internal and external balance, but tangency at $\mathrm{L}$ must mean the price of imports relative to home-produced goods is higher than the level needed for internal and external balance (the expenditure line is steeper than FG). The significance of policy sectors A, B, C and D is that they indicate the necessary direction needed for real expenditure and the relative price to restore internal and external balance. As each zone contains two policy sectors, Corden first echoes Meade by explaining how the necessary direction of only one policy instrument is clear in each zone, and then Swan by explaining how the appropriate policy response requires knowledge of which policy sector the economy is in, rather than which zone.

\section{Selective Switching Policies and Absorption}

Johnson's distinction between general and selective switching policies and his focus on the absorption approach were both highlighted by Corden. Whereas Swan and Salter used their diagrams to show the effects of general switching policies, Corden distinguished himself by

\footnotetext{
${ }^{14}$ Corden (1960, p. 8) notes that some may object to the use of the indifference curve to indicate constant levels of real expenditure (social welfare). For the purposes of this paper, what matters is that the indifference curve is used to highlight ideas previously expressed by Meade and Swan.
} 
examining selective switching policies - namely, import restrictions and tariffs - which made his analysis more relevant to Australian economic policy in that era. He also used his model to graphically illustrate the futility of an expenditure-switching policy alone at or above full employment. Since the success of such a policy relies on a reduction in real absorption, Corden (1960, p. 17) states that expenditure-reduction is the correct instrument to associate with external balance when an economy is fully employed. 


\section{A Non-Traded Export: The Dependent Economy Model}

\section{Abroad \\ Mundell, Johnson and the Monetary Approach to the Balance of Payments}

By the end of 1960, three graphical models of internal and external balance had been developed by Australians economists, each emphasising the role played by the price of traded goods relative to non-traded goods in balance of payments adjustment. James Meade's influence, however, did not end there. Robert A. Mundell (1932-) studied under Meade at the LSE in 1955-56, and he went on to take Meade's two-instrument, two-target approach in a different direction to the Australians. Meade (1951, pp. 100-107) had anticipated aspects of Mundell's future work by highlighting how fiscal and monetary policy differ in their overall effects on the balance of payments because of capital flows - even if their effects on domestic expenditure and the trade balance are identical. The Australian response was to treat capital flows as an exogenous variable and focus instead on relative price adjustments, but Mundell (1962) used the domestic interest rate as the policy instrument used to target external balance. He developed a conceptually similar model to the Swan diagram, with the domestic interest rate on one axis and the budget surplus on the other. The essence of his model is that a balance of payments deficit can be corrected by raising interest rates to initiate capital inflows, with fiscal policy then used to offset the employment reducing effects of higher interest rates. The practical utility of this model was a reflection of the policy environment of the era. With exchange rates fixed under the Bretton Woods regime, Mundell ${ }^{15}$ showed how internal and external balance could still be maintained with an appropriate mix of monetary and fiscal policy (eds Frenkel \& Johnson 1976, pp. 32-33).

The use of monetary policy to maintain external balance formed the basis of the monetary approach to the balance of payments. The monetary approach has links with David Hume's price-specie-flow mechanism but was formally developed by Harry G. Johnson, Robert A. Mundell, and their students at the University of Chicago during the 1960s and 1970s. Johnson (1923-1977), perhaps the preeminent figure in international economics of his generation, was an extraordinarily prolific writer who published over 500 academic articles in his relatively short lifetime (see Corden et al. 2001). In 'Towards a General Theory of the Balance of

\footnotetext{
${ }^{15}$ Mundell's pioneering analysis of fiscal and monetary policy under perfect capital mobility is now widely known through the Mundell-Fleming model. His prolific writings in the 1960s in this field and optimum currency area theory earned him the Nobel Prize in Economics in 1999 and are collected in International Economics (1968).
} 
Payments' (1958), Johnson not only coined expenditure-switching and expenditure-changing policies in his discussion of the absorption approach, he also provided one of the first expositions of the monetary approach to the balance of payments ${ }^{16}$. The essence of the monetary approach is that disequilibrium in the balance of payments leads to an increase or decrease in a country's foreign exchange reserves, which itself implies either an excess demand for or excess supply of money. Restoring equilibrium in the money market corrects the disequilibrium in the balance of payments and ensures the rate of change of foreign exchange reserves is zero (Frenkel \& Johnson 1976, pp. 21-22). Therefore, as balance of payments disequilibria are monetary phenomena, monetary policy should be used to correct them.

\section{Ivor Frank Pearce}

The monetary approach out of the University of Chicago and the lesser-known Australian approach out of the ANU were the two most recent developments in balance of payments theory in the 1960s. How the Australian contribution was noticed abroad is itself an interesting story. In 1961, Ivor Frank Pearce, a fellow economist in Swan's department at the ANU, published 'The Problem of the Balance of Payments' in the International Economic Review. Pearce used a two-country algebraic model with exportables, importables and nontraded goods to examine the effect on the balance of payments of currency depreciation at full employment. Although Pearce differed from the other Australians by not assuming constant terms of trade, he still concluded that the price of traded goods relative to non-traded goods was more important in the adjustment process than the terms of trade (Pearce 1961, p. 26). But despite drawing similar conclusions, Pearce's paper contained no reference to the earlier work of his ANU colleagues, Swan and Salter. Heinz Wolfgang Arndt (1976), a fellow economist at the ANU at the time, explained in an interesting note the convoluted reasons why acknowledgement was deemed to be unnecessary, but the consequences were that some international scholars erroneously cited Pearce as the originator of the approach and, more interestingly, then used Pearce's conclusions to tread intellectual ground covered by Australians years earlier.

\footnotetext{
${ }^{16}$ The other being the paper by Jacques J. Polak (1957) of the International Monetary Fund.
} 


\section{Ronald McKinnon}

A notable example is Ronald McKinnon's influential article, 'Optimum Currency Areas' (1963). McKinnon used the ratio of traded goods to non-traded goods to indicate the degree of openness of an economy, and though his general concern was how the openness of an economy affected the desirability of a common currency area, his discussion veered into areas previously covered by Australians before Pearce. He broached the topic of how monetaryfiscal policy and flexible exchange rates can best be combined to simultaneously achieve full employment, balanced international payments and stable internal prices in a small open economy. McKinnon noted that Meade had considered internal and external balance as targets but added that 'joint consideration of all three is not usually done'. Swan, of course, had focused on this issue in his 1953 seminar, which had since been published in the Economic Record in 1960. McKinnon went on to describe a 'simple model' of a small country in which the terms of trade are assumed to be unaffected by domestic policy. The effect of a depreciation in his model was to raise the price of traded goods relative to non-traded goods, which then induced consumption and production side responses that improved the trade balance. These effects were described in words, much like Wilson, Swan and Meade had done before Salter's diagrammatic exposition. Yet credit went to Pearce and not his predecessors for highlighting the importance of the price of traded goods relative to non-traded goods in balance of payments adjustment (McKinnon 1963, p. 719).

\section{Anne Krueger}

Anne Krueger (1969) also cited Pearce's article in in her comprehensive review of balance of payments theory. Krueger, an American economist with strong Australian roots ${ }^{17}$, regarded the analysis of non-traded goods as well as the monetary approach to the balance of payments as two 'radical' changes in the theory of exchange rate adjustment over the previous two decades. After summarising the conclusions of Pearce's article, she then wrote in 1969: 'To date, to this writer's knowledge, no other payments models have been forthcoming which further explore the role of home goods. ${ }^{21}$, Krueger explained in a footnote that she was working on a upcoming paper that developed a model with non-traded goods, traded goods and money (Krueger 1969, p. 10). That paper, eventually published as 'The Role of Home Goods and Money in Exchange Rate Adjustments’ (1974), combined the analysis of non-

\footnotetext{
${ }^{17}$ Krueger, whose parents were Australian, was a visiting professor at Monash University and the ANU on multiple occasions from the 1970s to the 1990s.
} 
traded goods with the monetary approach to the balance of payments. Krueger's article concerned the consequences of a devaluation within the monetary framework, whereby a devaluation raises the general price level and reduces the value of real money balances. Individuals then hoard money to restore the real value of their money holdings, which results in a reduction in expenditure (increase in saving) that improves the trade balance. The effect on real money balances is the link to the absorption approach. Krueger analysed this effect in a two-country model with traded and non-traded goods, which she considered a hybrid of Pearce's and others.

\begin{abstract}
Throughout, it is assumed that full employment is maintained, and that outputs of goods are functions of relative prices only. In addition, it is assumed that the country under discussion is small, and cannot affect the international prices at which it buys and sells goods. The former assumption has been widely used in models of trade balance determination, e.g. those of Pearce [7], Hahn [1] and Negishi [6]. The latter assumption is rather more limiting, since it ignores any effects on the terms of trade that might result from exchange rate changes. It is useful largely because it enables vast simplifications of the model, and highlights important aspects of the adjustment process that are obscured by the terms of trade question. In particular, traded goods may be treated as a composite commodity at any money exchange rate, since their relative prices will remain unchanged. (Krueger 1974, p. 143)
\end{abstract}

Though the models differed in emphasis, Krueger had gone through exactly the same thought process that Salter had over a decade earlier but, at her time of writing, was evidently unaware of his prior contribution. She used the small country constant terms of trade assumption to treat traded goods as a composite commodity, which allowed her to construct an identical diagrammatical model with traded goods and non-traded goods on either axis. Changes in the relative price then affected the production and consumption position of the economy (the 'adjustment process').

\title{
Rudiger Dornbusch
}

It was within the context of the monetary approach that Rudiger Dornbusch (1942-2002) became acquainted with the Australian model. Dornbusch completed his undergraduate studies at the University of Geneva in 1966 and received his PhD - under Harry G. Johnson, Robert A. Mundell and Stanley Fischer - from the University of Chicago in 1971. Like Krueger (1974), Dornbusch's thesis also examined the consequences of a devaluation within the monetary framework. Two revised portions of his thesis were published in 1973 
(Dornbusch 1973a, 1973b). The first included a citation of Pearce's article but considered the effects of devaluation in a two-country model without non-traded goods. The second introduced a model with non-traded goods and constant terms of trade, but Krueger's as yet unpublished paper was cited (among others) and not Salter's. Hence it does not appear that Dornbusch was fully aware of the Australian contribution during his PhD study. This had changed by 1972, however, when he presented a seminar paper at a conference hosted by the University of Chicago's Graduate School of Business (see ed. Aliber 1974). Dornbusch’s paper, titled 'Real and Monetary Aspects of the Effects of Exchange Rate Changes' (1974), combined the Australian model of non-traded goods with the monetary model used by Krueger.

This paper investigates the role and effects of exchange rate changes in a simple general equilibrium model of a small open economy. The purpose of the analysis is to combine two strands of literature that respectively view the sources of balance-of-payments difficulties and the effects of devaluation as "monetary" and "real." A monetary view of devaluation would emphasize the role of the real value of cash balances while the alternative approach would place primary emphasis on relative prices and real wages, a divergence of views not entirely unlike the earlier debate over "elasticity" and "absorption" approaches. (Dornbusch 1974, p. 64)

Dornbusch, who collectively cited Swan, Meade (1956), Salter and Corden for their development of the 'dependent economy model', appears to have been the first international scholar to recognise the related work of these individuals. 


\section{Rudiger Dornbusch and Beyond}

\section{'Real and Monetary Aspects of the Effects of Exchange Rate Changes'}

Dornbusch's 1974 paper was primarily focused on the monetary approach to the balance of payments, but it also included two refinements to the dependent economy model. The first relates to the supply side assumptions of the Salter model. Salter (1959, p. 228) described the production possibility frontier as the possible combinations of traded and non-traded goods that could be produced 'given home factor supplies, technical knowledge, natural resources, etc'. His generality with respect to factors of production led him to describe movements along the production possibility frontier due to changes in the relative price as 'movements of resources' from one sector to another. This masked the forces at work in the underlying factor markets: do all factors of production move between sectors or only particular factors of production? Dornbusch (1974, p. 64) addressed this by incorporating the supply side assumptions of the specific factors model.

\section{The Specific Factors Model}

The specific factors model was a very recent addition to international trade theory at the time. Its development is generally credited to Paul Samuelson (1971) and Ronald Jones (1971), though Michael Mussa (1974) and Jacob Viner (1932) are also often mentioned ${ }^{18}$. The model assumes an economy that can produce two goods with three factors of production, all of which are fixed in supply. One of these factors of production is mobile between sectors, whereas the other two are specific to a certain industry in the short run. In terms of the Salter model, Dornbusch assumes that labour is perfectly mobile between the traded and non-traded sectors, but the capital stock is divided between capital specific to the traded sector and capital specific to the non-traded sector. Under these assumptions, the 'movement of resources' that Salter referred to in response to a relative price change are movements of labour alone from sector to sector. This made Dornbusch's adaptation of Salter's model far more precise in terms of predicting the practical supply side response to a change in the relative price. Among his reasons for adopting the specific factors model assumptions, Dornbusch (1974, p. 69) cited the compelling realism they provide for short-run analysis and the relationship they yield between real wages and the price of traded goods relative to nontraded goods. The key notion behind this latter point involves product wages. A higher price

\footnotetext{
${ }^{18}$ Ronald Jones and Michael Mussa were Dornbusch’s colleagues at the University of Rochester at the time.
} 
of traded goods relative to non-traded goods, for instance, lowers the product wage in the traded sector and increases the product wage in the non-traded sector. This leads to increased employment and output in the traded sector and reduced employment and output in the nontraded sector.

\section{Deriving the Internal and External Balance Curves}

Dornbusch's second refinement linked the Salter and Swan diagrams. Although the internal and external balance curves in the Swan diagram trace out internal and external equilibria for different relative prices and levels of real expenditure, Swan did not explain how the curves were derived. Corden (1960, p. 20) pointed this out in his own paper when he described the Swan diagram as being 'magnificently simple' but added that it was 'a clock without a visible mechanism. It does not show how the internal and external balance curves are derived'. Dornbusch addressed this by showing how the Swan diagram can be derived from the Salter model $^{19}$.

Dornbusch's analysis focused on the price of traded goods relative to non-traded goods, with notation as follows:

$$
v \equiv P_{T} / P_{N}
$$

The output of traded goods and non-traded goods is a function of the relative price, $v$ :

$$
Y_{T}=Y_{T}(v) \quad Y_{N}=Y_{N}(v)
$$

The demand for traded and non-traded goods depends on the relative price, $v$, and real expenditure, $E$ :

$$
D_{T}=D_{T}(v, E) \quad D_{N}=D_{N}(v, E)
$$

Real expenditure, $E$, and real output, $Y$, are both measured in terms of non-traded goods:

$$
E \equiv v D_{T}+D_{N} \quad Y \equiv v Y_{T}+Y_{N}
$$

Preferences in the Salter model are assumed to be homothetic, which means income consumption curves for each relative price are straight lines through the origin. Figure 7

\footnotetext{
${ }^{19}$ The diagrammatic exposition is clearer in Dornbusch's 1974 paper, but his notation is clearer in his 1980 textbook and has been adopted in this paper. Note that Dornbusch (1974) has traded goods on the vertical axis and non-traded goods on the horizontal axis.
} 
shows the derivation of the Swan diagram (lower panel) from the Salter model (upper panel). Indifference curves have been omitted for clarity.

Figure 7: Deriving the Swan Diagram from the Salter Model

\section{Salter Model}

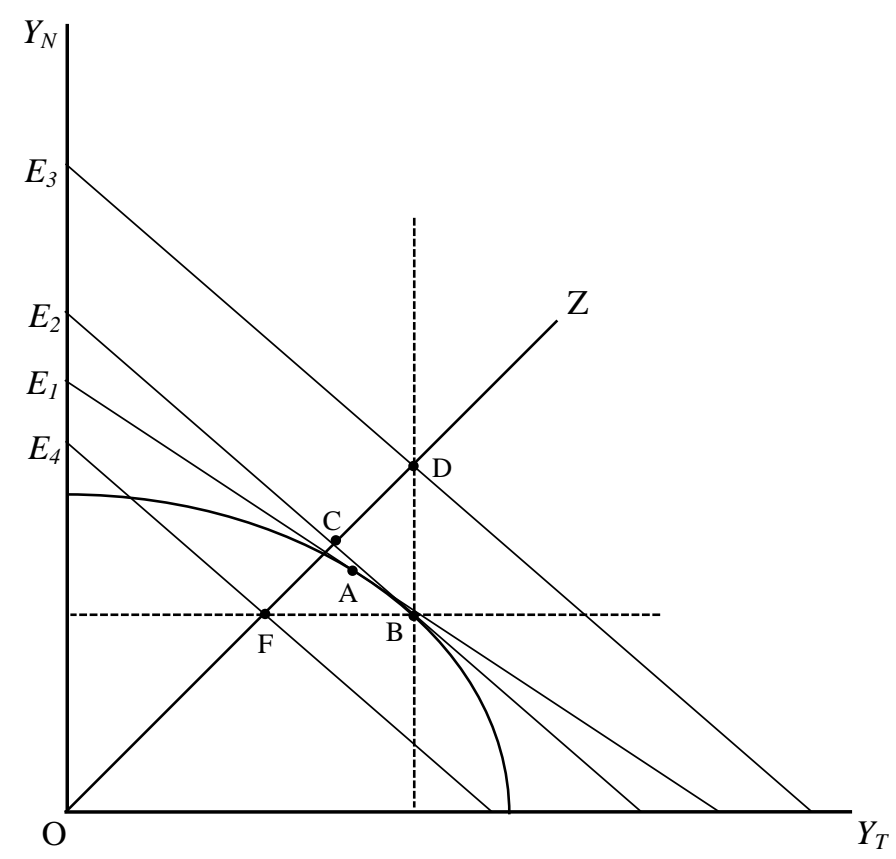

Swan Diagram

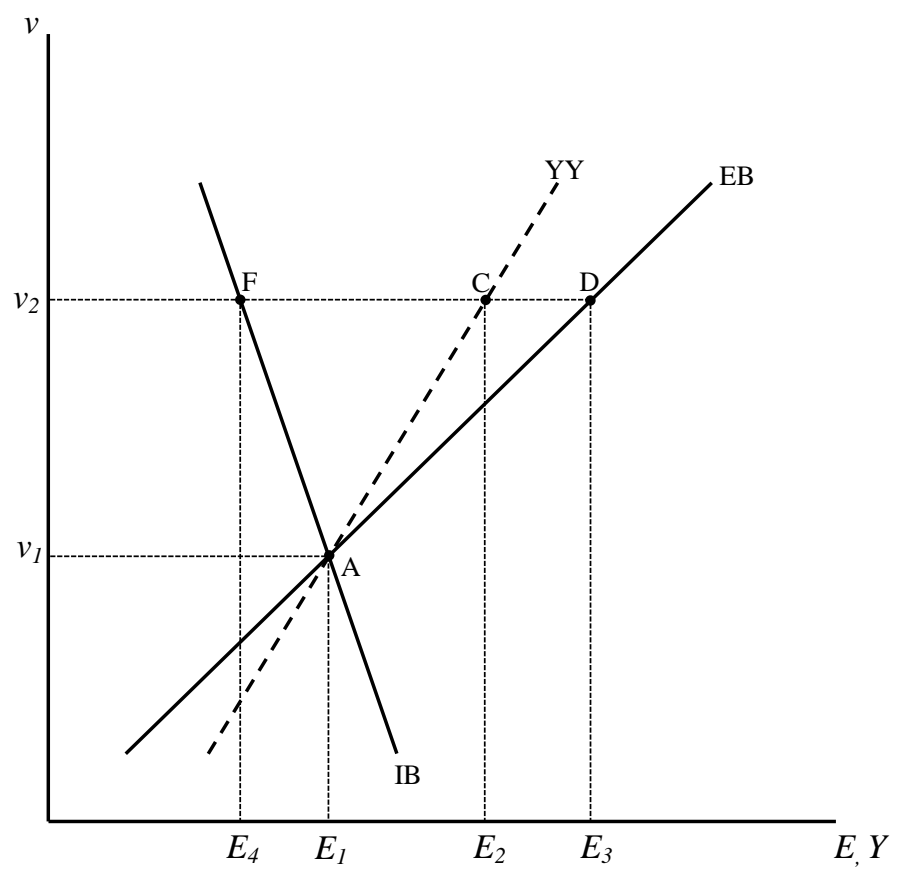


The starting position is point A in the Salter diagram, a situation of internal and external balance. The value of output in terms of non-traded goods at point $\mathrm{A}$ is shown by the vertical intercept $E_{1}$. It is now assumed that the value of $v$ increases (e.g., through devaluation) so that the slope of the full employment income line steepens. The steeper full employment income line shifts production to point $B$, which increases the value of output in terms of non-traded goods to $E_{2}$. The income consumption curve for the new relative price is shown as a straight line from the origin, OZ. It connects points of tangency between the expenditure line and indifference curves as domestic expenditure changes. Assuming that real expenditure equals real income at the new relative price, the consumption point for the economy will be at point C. With the consumption and production points no longer coinciding, point $C$ is a situation of over-full employment and balance of payments surplus, since it lies above and to the left of B. Restoring external balance requires that consumption be moved to point $\mathrm{D}$, which entails an increase in real expenditure to $E_{3}$. Restoring internal balance requires that consumption be moved to point $F$, which entails a reduction in real expenditure to $E_{4}$. This is an example of a conflict between policy objectives - as identified by Meade and Swan - and this notion links the two models.

The Swan diagram drawn in the lower panel of figure 7 shows the equivalent movements. Point A represents internal and external balance with a relative price $v_{1}$ and level of real expenditure $E_{1}$. The higher relative price causes a vertical movement from $v_{1}$ to $v_{2}$, and the resultant increase in real output/expenditure is shown by the horizontal movement from $E_{1}$ to $E_{2}$ at point C. Connecting points A and C traces out Dornbusch's YY line, which shows how the value of output in terms of non-traded goods changes as the relative price changes. Dornbusch uses this line - an addition to Swan's original diagram - to explain the absorption approach. Restoring external balance at the new relative price $v_{2}$ requires an increase in real expenditure from $E_{1}$ to $E_{3}$ at point $\mathrm{D}$. Connecting points $\mathrm{A}$ and $\mathrm{D}$ traces out Swan's upward sloping external balance line EB. Similarly, restoring internal balance at the new relative price $v_{2}$ requires a reduction in real expenditure from $E_{1}$ to $E_{4}$ at point $\mathrm{F}$. Connecting points $\mathrm{A}$ and $\mathrm{F}$ traces out Swan's downward sloping internal balance line $\mathrm{IB}^{20}$. Having now traced out the internal and external balance lines, it is clear that point $\mathrm{C}$, which lies to the right of the

\footnotetext{
${ }^{20}$ Dornbusch (1980, pp. 100-102) explains how it is theoretically possible for the internal balance line to be positively sloped if income effects dominate substitution effects (demand and supply side) following a relative price change. The practical implication is that a devaluation worsens the internal employment situation. Such a consequence would violate the spirit of Meade and Swan's analysis.
} 
internal balance line and to the left of the external balance line, is a situation of over-full employment and balance of payments surplus, just as depicted in the Salter diagram.

\section{The Real Exchange Rate}

In presenting his paper at the 1972 seminar, Dornbusch had identified the contributions made by Australian economists and offered two refinements to the dependent economy model. A third refinement came after an article by fellow University of Chicago alumni. In 1973, Eitan Berglas and Assaf Razin, both of Tel Aviv University, published an article in the Journal of Economics which coined a new term for the relative price that played the central role in the Australian model. The price of traded goods relative to non-traded goods was assigned the function of the 'real exchange rate':

In the conventional approach, it is usually assumed that all goods are tradable. This means that for a small country, all commodity prices (and thereby the terms of trade) are determined by the rest of the world. Under these assumptions, devaluation does not change relative commodity prices; instead, it changes internal prices in terms of the home currency .... In the case of two large countries, analysis of devaluation emphasizes the changes in the terms of trade. In the case of a small country where the terms of trade are given, the only possible change in relative prices is in terms of prices of tradable to non-tradable goods. We shall hereafter refer to this price ratio as the 'real exchange rate'. Thus, changes in the real exchange rate are comparable to changes in the nominal exchange rate when the quantity of money is held constant (Berglas \& Razin 1973, pp. 180181).

The explanation provided by Berglas and Razin is the same as the argument put forth by Trevor Swan in response to James Meade's Balance of Payments. As a small country cannot affect its terms of trade, a devaluation in a two-good model increases the domestic prices of exportables and importables proportionately and thus leaves the relative price unchanged; hence, there is no real economic effect. In contrast, a devaluation in a three-good model with the price of traded goods fixed in foreign currency and the price of non-traded goods held constant in domestic currency - does unambiguously change a relative price, the real exchange rate, and thus has a real effect. The real exchange rate can be written as:

$$
\text { Real Exchange Rate }=\frac{P_{T}}{P_{N}}=\frac{e P_{T}^{*}}{P_{N}}
$$

where $e$ is the domestic currency price of foreign exchange, $P_{T}^{*}$ is the foreign currency price of traded goods, and $P_{N}$ is the domestic currency price of non-traded goods. As both prices are 
assumed constant, an increase in $e$ (devaluation) results in an increase in the relative price of traded goods and thus a real devaluation. Intuitively, more units of non-traded goods must now be exchanged for each unit of traded goods. Dornbusch went on to emphasise this point in his subsequent treatment of the Australian model (Dornbusch 1975), though he did not explicitly refer to the relative price as the real exchange rate until he devoted chapter six of his textbook Open Economy Macroeconomics (1980) to a discussion of the dependent economy model.

\section{Open Economy Macroeconomics}

Dornbusch's inclusion of the dependent economy model in a mainstream international economics text was instrumental to its popularisation abroad. His adoption of the term 'the real exchange rate', though fundamentally a semantic change, also caused a noticeable variation in terminology after 1980. This change in terminology is important in a contemporary setting because it provides a connection between the model's development and the subsequent research that its conclusions engendered. Dornbusch anticipated this subsequent research in Open Economy Macroeconomics with an enhancement to the model. He again derived the Swan diagram from the Salter model, but this time he showed how an array of exogenous changes could shift Swan's internal and external balance curves. Swan (1963a, p. 386) had argued in his 1955 seminar that the internal and external balance curves would shift if any of the factors taken as given - productivity, the terms of trade, capital flows and other financial transfers - were to change, yet his failure to show how the Swan diagram was derived hid the underlying process. Salter discussed exogenous changes to capital inflows and the terms of trade, but the model's conclusions are best understood when the two diagrams are integrated. Dornbusch (1980, pp. 103-111) considers changes in preferences, financial transfers, productivity and the terms of trade, but future research focused mainly on changes in capital flows, productivity, and the terms of trade. These changes are presented in figure 8 . 
Figure 8: Exogenous Shocks in the Salter and Swan Models

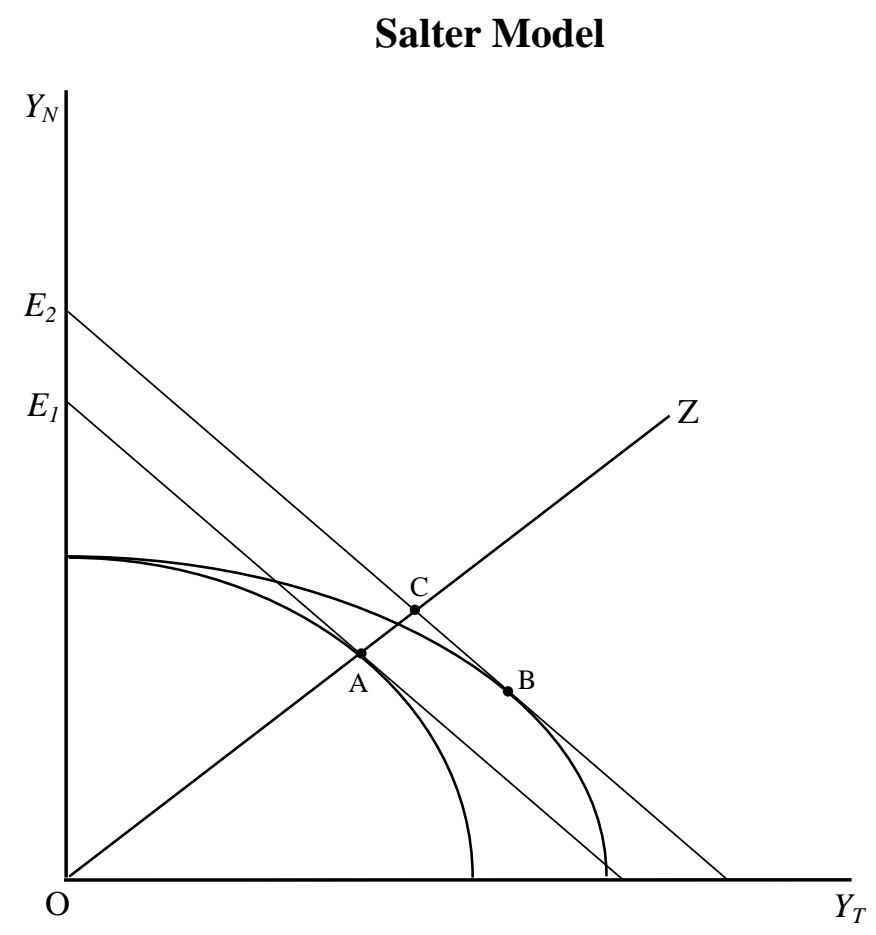

Swan Diagram

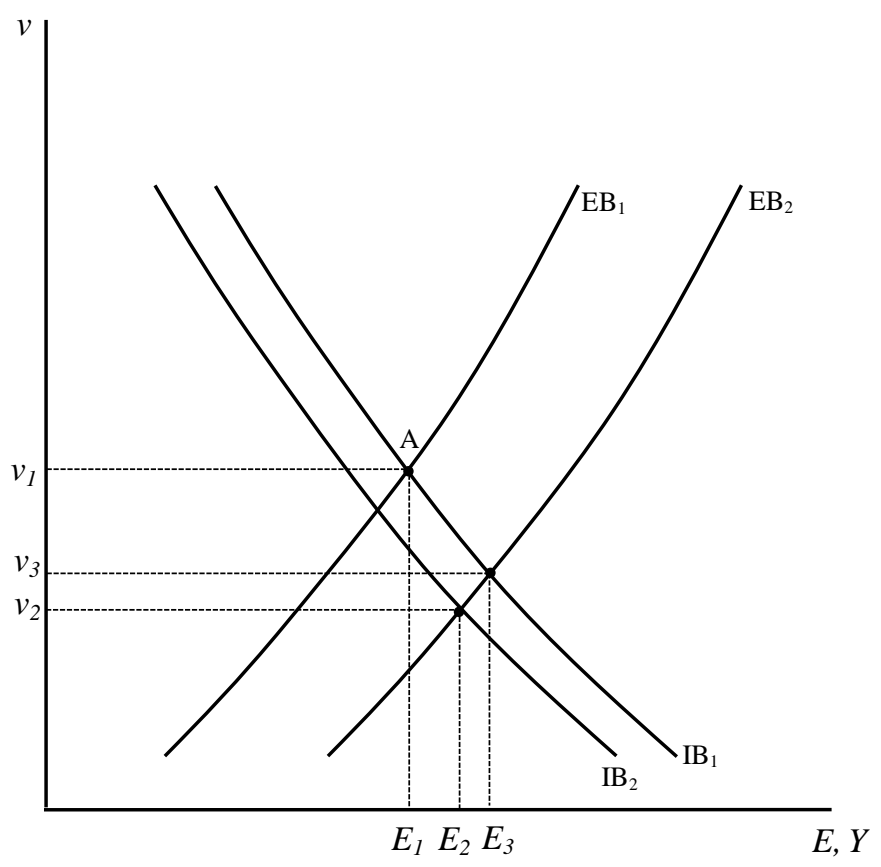




\section{Capital Inflow}

If the economy is in internal and external balance, a shift of the internal or external balance curve (or both) must result from an exogenous change which creates an internal or external disequilibrium (or both) at the current real exchange rate and level of real expenditure. The case of an exogenous capital inflow is shown in the Salter and Swan diagrams in figure 8. Beginning with internal and external balance at point A in the Salter diagram, the capital inflow is represented by a parallel outward shift of the domestic expenditure line from $E_{1}$ to $E_{2}$. Holding the real exchange rate and real expenditure constant, the production and consumption points remain at $\mathrm{A}$, where both the non-traded and traded goods markets clear. However, the economy is no longer in external balance. External balance requires that the demand for traded goods exceed the supply of traded goods by the horizontal distance between $E_{1}$ and $E_{2}$ - the size of the capital inflow in terms of traded goods. The capital inflow now means that point $\mathrm{A}$ is a situation of internal balance and balance of payments surplus. This is shown in the Swan diagram as a shift of the external balance curve from $\mathrm{EB}_{1}$ to $\mathrm{EB}_{2}$. Internal and external balance is restored with a real appreciation from $v_{1}$ to $v_{3}$ and an increase in real expenditure from $E_{1}$ to $E_{3}$. The real appreciation is essential because the expenditure effect only partly offsets the capital inflow on the current account (the move from A to $\mathrm{C}$ in the Salter diagram) $)^{21}$.

\section{Productivity Change}

Changes in productivity shift the production possibility frontier in the Salter model. Figure 8 shows an improvement in productivity that is specific the traded sector, meaning more traded goods can be produced for any given level of non-traded goods. The effect is to shift the production point of the economy from $\mathrm{A}$ to $\mathrm{B}$ at the existing real exchange rate. The upshot is that the situation at the initial real exchange rate and level of real expenditure is now one of overemployment and balance of payments surplus. In terms of the Swan diagram, the internal balance curve shifts from $\mathrm{IB}_{1}$ to $\mathrm{IB}_{2}$ and the external balance curve shifts from $\mathrm{EB}_{1}$ to $\mathrm{EB}_{2}$. Simultaneous equilibrium is restored with a real appreciation from $v_{1}$ to $v_{2}$ and an increase in real expenditure from $E_{1}$ to $E_{2}$.

\footnotetext{
${ }^{21}$ This is precisely the point Wilson made in 1931. Part of the capital inflow would fall on traded goods (the income effect), but for the whole of the loan to be 'transferred in goods', the price of non-traded (domestic) goods must rise relative to traded (international) goods: a real appreciation must occur.
} 


\section{Terms of Trade Change}

Although it is assumed that the terms of trade cannot be influenced by domestic factors, exogenous changes in the terms of trade - caused by factors abroad - can still occur. Salter (1959, pp. 234-235) examined the effect of an exogenous improvement in the terms of trade (e.g., an increase in the world price of exportables) in a manner identical to an increase in productivity in the traded sector. He argued that the improved terms of trade means each exportable produced can now be exchanged for more traded goods. Representing a terms of trade shock in this way leads to changes in the Salter and Swan diagrams that are analogous to productivity improvements in the traded sector, as described above. Dornbusch (1980, pp. 109-110) differs from Salter by disaggregating exportables and importables, yet his conclusions are the same: the favourable movement in the terms of trade results in a new equilibrium in which the real exchange rate has appreciated and real expenditure is higher.

\section{Structural Change}

There is a very important difference between exogenous changes that shift the internal and/or external balance curves and changes that alter the real exchange rate and/or level of real expenditure but leave the internal and external balance curves unchanged. In the latter case, the Swan diagram shows that a disequilibrium situation can be resolved with a combination of real exchange rate and real expenditure adjustments that return the economy to its initial equilibrium. In contrast, exogenous changes to capital flows, productivity and the terms of trade result in a new equilibrium in which the real exchange rate and level of real expenditure have changed. The change to the equilibrium real exchange rate alters the structure of the economy because it entails a change in the composition of the economy's production of traded and non-traded goods. What capital inflows, productivity improvements in the traded sector and favourable terms of trade shocks have in common is that they are all predicted to appreciate the real exchange rate. This real appreciation reduces the price of traded goods relative to non-traded goods and leads, via the labour market, to a reorientation of production away from traded goods to non-traded goods. 


\section{The Real Appreciation Problem}

The predicted consequences of capital flows has motivated much subsequent research on capital movements in small open economies ${ }^{22}$. Corden (1994, p. 60) explains a scenario experienced by many countries in which a private investment boom is financed by capital inflow. The inflow of capital necessitates a real appreciation to maintain internal and external balance, but this leads to a loss of competitiveness for export and import-competing industries. He calls this structural change the 'real appreciation problem'. The implications of the real appreciation problem are particularly interesting when countries have fixed exchange rates. Since the fixed nominal exchange rate keeps the domestic currency price of traded goods constant, the real appreciation must come through an increase in the price of non-traded goods. If the capital inflow is reversed, however, restoring internal and external balance then requires a reduction in the price of non-traded goods. Considerable problems can occur if the prices of non-traded goods are upwardly flexible but downwardly rigid (in this case it is useful to consider nominal wages). If the real exchange rate cannot adjust to restore internal and external balance, then a potential conflict between full employment and external balance may arise. Paul Krugman (2012) has used such arguments to describe the recent experience of the eurozone, where the nominal exchange rate is naturally fixed at one-one among member countries. Krugman argues the creation of the euro led to capital flows from the core (e.g., Germany) to the periphery (e.g., Greece and Spain) which substantially raised domestic prices and wages in the periphery relative to the core. The onset of the euro-crisis brought these inflows to a halt, but the requisite reduction in nominal wages ('internal devaluation') has been extremely difficult to engineer. Krugman's analysis is couched in the context of Mundell's optimum currency area theory, but the same theoretical argument can be made within the dependent economy model framework.

\section{The Gregory Effect and Dutch Disease}

The predicted effects of productivity growth in the traded sector motivated another field of research that has also had a strong Australian influence: the 'Gregory effect' or 'Dutch disease' phenomenon ${ }^{23}$. Max Corden has once again been a prominent figure in this field. His

\footnotetext{
${ }^{22}$ See, for example, Athukorala and Rajapatirana (2003), Calvo, Leiderman and Reinhart (1993, 1996), Reinhart and Reinhart (2008), and Sachs (1999).

${ }^{23}$ The 'Gregory effect' refers to Robert Gregory's (1976) article where he argues that the expansion of Australian mineral exports from the mid 1960s to mid 1970s caused a real appreciation that adversely affected existing export and import-competing sectors. 'Dutch disease' was coined by The Economist magazine in 1977 to describe similar effects experienced by Dutch manufacturers after North Sea natural gas discoveries in 1959.
} 
well-known article with J. Peter Neary (1982), which drew upon prior work by fellow Australians Robert Gregory (1976), Richard Snape (1977) and Michael Porter (1978), examines the structural consequences of a boom in one of two traded sectors in a three-sector economy with non-traded goods. Their 'core model', which includes the assumptions of the specific factors model and is described as a 'variant' of Salter's, predicts that a boom in one of the traded sectors - caused by exogenous technical change, a windfall discovery of resources or an exogenous increase in the terms of trade - leads to a real appreciation that results in an unambiguous reduction in employment in the other - 'lagging' - traded sector. Corden (2012) has recently applied the model to explain the current Australian economic situation. He argues that the resources boom has led to a real appreciation that has placed pressure on lagging sectors of the economy such as manufacturing, tourism, education and agriculture. The impetus for this boom was the large increase in Australia's terms of trade, followed by capital inflow and investment in the mining sector. In that respect, the Australian situation is reflective of three shocks occurring at once, all of which result in real appreciation.

\section{The Australian Contribution to International Trade Theory}

The real appreciation problem and Dutch disease both highlight the enduring practical usefulness of the dependent economy model. Its principal contribution, however, is more fundamental, for the story of the model reflects the evolution of the theory of balance of payments adjustment. Beginning with David Hume and the price-specie-flow mechanism, the terms of trade was seen as the sole equilibrating factor that brought the balance of payments into equilibrium. This remained the dominant view well into the $20^{\text {th }}$ century, and leading international trade theorists such as Frank Taussig and Jacob Viner were among its proponents. With the Keynesian revolution of the 1930s came a distinct explanation which emphasised the role of income/expenditure effects in balance of payments adjustment. James Meade integrated these disparate views by underlining the role played by relative price (terms of trade) and income effects in restoring external balance. The Australian contribution that emerged after James Meade's seminal text acknowledged relative price and income effects but identified the real exchange rate - instead of the terms of trade - as the key relative price. This distinction between the terms of trade and real exchange rate had been foreshadowed a generation earlier by another Australian economist, Roland Wilson. The significance of this contribution is evident in the textbook treatment of this issue over time: Frank Taussig's International Trade (1927) focused on relative price effects through the terms of trade; James 
Meade's The Balance of Payments (1951) focused on the terms of trade and income/expenditure effects; and modern international trade texts such as Krugman and Obstfeld's International Economics (2003, pp. 435-436) now emphasise the role played by income/expenditure effects and, principally, the real exchange rate in balance of payments adjustment. 


\section{Conclusion}

The Australian contribution to international trade theory is the distinction between the terms of trade and the real exchange rate in balance of payments adjustment. This emphasis on the real exchange rate is now a hallmark of modern theory, but from David Hume's (1752) pricespecie-flow mechanism to James Meade’s The Balance of Payments (1951) the terms of trade was seen as the critical relative price in the adjustment mechanism. Roland Wilson first made this distinction in 1931, but it was not until the 1960s that the Australian emphasis on the real exchange rate gained widespread attention abroad. This Australian contribution is an inherent feature of the dependent economy model, which was developed by Trevor Swan, Wilfred Salter and Max Corden in the 1950s and early 1960s, and later by Rudiger Dornbusch. It has been shown that much of the theoretical groundwork for this model was provided by Roland Wilson and James Meade. A brief summary of each contribution is given below.

Roland Wilson introduced three key aspects of the dependent economy model in his book Capital Imports and the Terms of Trade (1931). First, he emphasised the importance of nontraded goods in the adjustment mechanism. From David Hume in 1752, to John Stuart Mill in 1871, to leading international trade theorists Frank Taussig and Jacob Viner (his PhD supervisor) in the 1920s, the terms of trade was seen as the crucial relative price in balance of payments adjustment. Wilson challenged economic orthodoxy by arguing instead that balance of payments adjustment occurs through a movement in the price of traded goods relative to non-traded goods. This relative price - the real exchange rate - became central to the graphical models developed by Swan, Salter and Corden. Second, Wilson provided the first explanation of how the real exchange rate adjustment mechanism worked. He argued that a change in the price of traded goods relative to non-traded goods causes consumption and production responses that combine to influence the trade balance. This adjustment process was explained later by Swan and Meade, and shown diagrammatically by Salter and Corden. Third, Wilson introduced the small country assumption of exogenously determined terms of trade. This assumption is common to the contributions made by Swan, Salter and Corden, and it formed the basis of Trevor Swan's theoretical objection to James Meade’s analysis.

When James Meade published his classic The Balance of Payments in 1951, he integrated two disparate explanations of balance of payments adjustment. There was the traditional emphasis on the terms of trade (which had now evolved into elasticity analysis) and the relatively new income adjustment mechanism (which began with Ohlin and was expanded upon after the 
Keynesian revolution). Meade used his two-country, two-commodity model to illustrate that adjustments in the terms of trade and domestic expenditure affect both the internal and external position of the economy. His fundamental contribution was the introduction of the twin policy objectives, internal and external balance. A country finding itself in any one of four possible disequilibrium situations could restore internal and external balance with a combination of relative price (terms of trade) and expenditure adjustments. Meade emphasised that the two policy targets of internal and external balance required at least two policy instruments to avoid any conflict between targets. His preference was to use price adjustments (changes to the nominal exchange rate and/or money wages) to target external balance and financial policy (fiscal and monetary policy) to target internal balance.

James Meade's analysis had a profound influence on Trevor Swan. His influence was visible in Swan's first paper (presented in 1953 and published in 1960) but was most clearly conveyed - along with the absorption approach - in his second paper through the Swan diagram (presented in 1955 and published in 1963). Swan used his diagram to illustrate many of Meade's core ideas, but the principal point was that relative price and expenditure adjustments are needed to simultaneously maintain internal and external balance. Where Swan differed from Meade was his choice of relative price. Meade had followed Frank Taussig and Jacob Viner in arguing that a nominal depreciation improved the trade balance through its effect on the terms of trade, but Swan objected to Meade's analysis by including Roland Wilson's small country assumption and emphasis on the role of non-traded goods (expressed as domestic money wages). A nominal depreciation improves the trade balance not because it raises the price of imports relative to exports (although this could also occur) but principally because it raises the price of traded goods relative to non-traded goods (a real depreciation). Swan's theoretical justification for this point came through Wilson's small country assumption. In a small country, a depreciation raises the price of exports and imports proportionately and leaves the terms of trade unchanged, but an improvement in the trade balance still occurs because the price of traded goods has risen relative to non-traded goods. Swan's was thus a very simple amendment to James Meade's framework. He acknowledged that relative price and expenditure adjustments were necessary to achieve internal and external balance, but he highlighted the real exchange rate - instead of the terms of trade - as being the crucial relative price. Meade had hinted at this effect in his brief treatment of nontraded goods in The Balance of Payments, but he erred in confining his attention to the terms of trade. He quickly came around to Swan's view when he visited Australia in 1956, and in 
his Nobel lecture he spoke of his regret at not devoting more time to the concept of the nontraded goods in The Balance of Payments (Meade 1977b).

Swan's adaptation of Meade’s framework inspired other graphical models by Wilfred Salter (1959) and Max Corden (1960). Salter's diagram is the quintessential exposition of the dependent economy model. He used the small country assumption of constant terms of trade to aggregate exportables and importables into a composite commodity, traded goods. With only traded goods and non-traded goods in the Salter model, there is only one relative price: the real exchange rate. Real exchange rate and expenditure adjustments are then used to maintain internal and external balance. Salter's contribution stands out because it provides a diagrammatical exposition of balance of payments adjustment. A real depreciation, for instance, shifts production from non-traded goods to traded goods and consumption from traded goods to non-traded goods. These demand and supply responses combine to improve the trade balance. Max Corden's model also demonstrated how internal and external balance requires a combination of real exchange rate and expenditure adjustments, but its distinguishing feature was its ability to analyse the effects of tariffs and import restrictions policies that were pertinent to the Australian economic situation at the time.

Rudiger Dornbusch's $(1974,1980)$ discovery of the model came through a peculiar set of circumstances, yet his contribution comprised a series of refinements. As a PhD student under Harry G. Johnson and Robert A. Mundell at the University of Chicago, Dornbusch was an important figure in the development of the monetary approach to the balance of payments. He therefore took an interest in a paper by Anne Krueger that combined the monetary approach with the Australian emphasis on non-traded goods - which Krueger knew of through Ivor Frank Pearce's article. Dornbusch identified the related contributions made prior to Pearce and introduced a series of refinements to the dependent economy model. First, he added precision to the Salter model by including the supply side assumptions of the specific factors model. Second, he integrated the Swan diagram and Salter model by showing how Swan's internal and external balance curves could be derived from the Salter model. Third, he adopted the terminology of Berglas and Razin (1973) and redefined the relative price in the dependent economy model as the real exchange rate. Fourth, he showed how exogenous changes shift Swan's internal and external balance curves and change the equilibrium real exchange rate (structural change). This final point provides a link to the real appreciation problem and Dutch disease, two modern strands of research that grew out of the dependent economy model. 


\section{Bibliography}

Alexander, SS 1952, 'Effects of a Devaluation on a Trade Balance', Staff Papers International Monetary Fund, vol. 2, no. 2, pp. 263-278.

Aliber, RZ 1974, National Monetary Policies and the International Financial System, University of Chicago Press, Chicago.

Arndt, HW 1976, 'Non-Traded Goods and the Balance of Payments: The Australian Contribution', Economic Record, vol. 52, no. 137, pp. 104-107.

Arndt, HW 1995, 'James Meade 1907-1995', History of Economics Review, no. 24, pp. 98100.

Athukorala, P \& Rajapatirana, S 2003, 'Capital Inflows and the Real Exchange Rate: A Comparative Study of Asia and Latin America', World Economy, vol. 26, no. 4, pp. 613-637.

Australia Parliament 1945, Full Employment in Australia, Commonwealth Government Printer, Canberra.

Berglas, E \& Razin, A 1973, 'Real Exchange Rate and Devaluation', Journal of International Economics, vol. 3, no. 2, pp. 179-191.

Bickerdike, CF 1920, 'The Instability of Foreign Exchange', The Economic Journal, vol. 30, no. 117 , pp. $118-122$.

Brigden, JB, Copland, DB, Dyason, EC, Giblin, LF \& Wickens, CH 1929, The Australian Tariff : An Economic Enquiry, 2nd edn, Melbourne University Press in association with Macmillan, Melbourne.

Brown, AJ 1942, 'Trade Balances and Exchange Stability', Oxford Economic Papers, no. 6, pp. 57-75.

Butlin, NG \& Gregory, RG 1989, 'Trevor Winchester Swan 1918-1989', Economic Record, vol. 65, no. 4, pp. 369-377.

Cairnes, JE 1874, Some Leading Principles of Political Economy Newly Expounded, Macmillan and Co., London.

Calvo, GA, Leiderman, L \& Reinhart, CM 1993, 'Capital Inflows and Real Exchange Rate Appreciation in Latin America: The Role of External Factors', Staff Papers International Monetary Fund, vol. 40, no. 1, pp. 108-151.

Calvo, GA, Leiderman, L \& Reinhart, CM 1996, 'Inflows of Capital to Developing Countries in the 1990s', The Journal of Economic Perspectives, vol. 10, no. 2, pp. 123-139. 
Coleman, W 2006, 'A Conversation with Max Corden', Economic Record, vol. 82, no. 259, pp. 379-395.

Coombs, HC 1994, From Curtin to Keating: the 1945 and 1994 White Papers on Employment: A Better Environment for Human and Economic Diversity? Available from: <http://hdl.handle.net/1885/47102>. [3 April 2013].

Corden, WM 1960, 'The Geometric Representation of Policies to Attain Internal and External Balance', The Review of Economic Studies, vol. 28, no. 1, pp. 1-22.

Corden, WM 1965, Recent Developments in the Theory of International Trade, Princeton University, Princeton.

Corden, WM 1968, 'Australian Economic Policy Discussion in the Post-War Period: A Survey', The American Economic Review, vol. 58, no. 3, pp. 88-138.

Corden, WM 1994, Economic Policy, Exchange Rates, and the International System, Oxford University Press, Oxford.

Corden, WM 1996a, 'James E. Meade, 1907-1995', Review of International Economics, vol. 4, no. 3, pp. 382-386.

Corden, WM 1996b, 'James Meade 1907-1995', Economic Record, vol. 72, no. 217, pp. 172174.

Corden, WM 2000, 'W. Max Corden (b. 1927)', in Exemplary Economists Volume II: Europe, Asia and Australasia, eds RE Backhouse \& R Middleton, Edward Elgar Publishing, Cheltenham, England.

Corden, WM 2012, The Dutch Disease in Australia: Policy Options for a Three-Speed Economy. Available from: $<$ http://melbourneinstitute.com/downloads/working_paper_series/wp2012n05.pdf > . [4 April 2013].

Corden, WM, Duesenberry, JS, Goodwin, CD, Hynes, JA, Lipsey, RG, Gideon, R, Samuelson, PA, Elizabeth Johnson, S \& Moss, LS 2001, 'Harry G. Johnson (19231977): Scholar, Mentor, Editor, and Relentless World Traveler', American Journal of Economics and Sociology, vol. 60, no. 3, pp. 601-649.

Corden, WM \& Neary, JP 1982, 'Booming Sector and De-Industrialisation in a Small Open Economy', The Economic Journal, vol. 92, no. 368, pp. 825-848.

Cornish, S 2002, Sir Roland Wilson: A Biographical Essay, Australian National University, Canberra.

Cornish, S 2004, 'W.E.G Salter', in The Biographical Dictionary of British Economists, ed. D Rutherford, Thoemmes Continuum, Bristol. 
Cornish, S 2007a, 'The Appointment of the ANU's First Professor of Economics', History of Economics Review, no. 46, pp. 1-18.

Cornish, S 2007b, 'Sir Roland Wilson (1904-1996)', in A Biographical Dictionary of Australian and New Zealand Economists, ed. JE King, Edward Elgar, Cheltenham, England, pp. 310-314.

Cornish, S 2012, Swan, Trevor Winchester (1918-1989) in Australian Dictionary of Biography, Australian National University, Online Edition, [16 April 2013].

Dornbusch, R 1973a, 'Currency Depreciation, Hoarding, and Relative Prices', Journal of Political Economy, vol. 81, no. 4, pp. 893-915.

Dornbusch, R 1973b, 'Devaluation, Money, and Nontraded Goods', The American Economic Review, vol. 63, no. 5, pp. 871-880.

Dornbusch, R 1974, 'Real and Monetary Aspects of the Effects of Exchange Rate Changes', in National Monetary Policies and the International Financial System, ed. RZ Aliber, University of Chicago Press, Chicago.

Dornbusch, R 1975, 'Alternative Price Stabilization Rules and the Effects of Exchange Rate Changes', The Manchester School, vol. 43, no. 3, pp. 275-292.

Dornbusch, R 1980, Open Economy Macroeconomics, Basic Books, New York.

Dowsett, WT \& Peters, RW 1964, 'Obituary: Wilfred Edward Graham Salter', Gazette of the University of Western Australia, vol. March.

Frenkel, JA \& Johnson, HG (eds) 1976, The Monetary Approach to the Balance of Payments, Allen \& Unwin, London.

Gregory, RG 1976, 'Some Implications of the Growth of the Mineral Sector', Australian Journal of Agricultural Economics, vol. 20, no. 2, pp. 71-91.

Groenewegen, PD \& McFarlane, B 1990, A History of Australian Economic Thought, Routledge, London.

Harcourt, GC 1962, 'Productivity and Technical Change', Economic Record, vol. 38, no. 83, pp. 388-394.

Harcourt, GC 2007, 'Wilfred Edward Graham Salter (1929-1963)', in A Biographical Dictionary of Australian and New Zealand Economists, ed. JE King, Edward Elgar, Cheltenham, England, pp. 243-245.

Harrod, R 1939, International Economics, Nisbet, London.

Hemming, MFW \& Corden, WM 1958, 'Import Restriction as an Instrument of Balance-ofPayments Policy', The Economic Journal, vol. 68, no. 271, pp. 483-510. 
Hicks, JR 1946, Value and Capital: An Inquiry into some Fundamental Principles of Economic Theory, 2nd edn, Clarendon Press, Oxford.

Hume, D 1752, Political Discourses. The Second Edition., The Making of the Modern World, Edinburgh. Available from: The Making of the Modern World. [12 February 2013].

Johnson, HG 1958, 'Towards a General Theory of the Balance of Payments', in International Trade and Economic Growth: Studies in Pure Theory, ed. HG Johnson, Allen \& Unwin, London, pp. 153-168.

Jones, RW 1971, 'A Three-Factor Model in Theory, Trade, and History', in Trade, Balance of Payments and Growth: Papers in International Economics in Honor of Charles P. Kindleberger, eds JN Bhagwati, RW Jones, RA Mundell \& J Vanek, North-Holland, Amsterdam, pp. 3-21.

Keynes, JM 1929, 'The German Transfer Problem', The Economic Journal, vol. 39, no. 153, pp. $1-7$.

Keynes, JM 1930, A Treatise on Money, Macmillan, London.

Keynes, JM 1936, The General Theory of Employment, Interest and Money, Macmillan, London.

King, JE 2007, A Biographical Dictionary of Australian and New Zealand Economists, Edward Elgar, Cheltenham, England.

Krueger, AO 1969, 'Balance-of-Payments Theory', Journal of Economic Literature, vol. 7, no. 1, pp. 1-26.

Krueger, AO 1974, 'The Role of Home Goods and Money in Exchange Rate Adjustments', in International Trade and Finance: Essays in Honour of Jan Tinbergen, ed. W Sellekaerts, Macmillan, London.

Krugman, PR 2012, Revenge of the Optimum Currency Area. Available from: $<$ http://www.nber.org/chapters/c12759.pdf>. [3 April 2013].

Krugman, PR \& Obstfeld, M 2003, International Economics: Theory and Policy, 6th edn, Addison Wesley, Boston.

Leontief, W 1936, 'Composite Commodities and the Problem of Index Numbers', Econometrica, vol. 4, no. 1, pp. 39-59.

Lerner, AP 1944, The Economics of Control: Principles of Welfare Economics, MacMillan Company, New York.

Marshall, A 1923, Money, Credit and Commerce, Macmillan, London.

McKinnon, RI 1963, 'Optimum Currency Areas', The American Economic Review, vol. 53, no. 4, pp. 717-725. 
Meade, JE 1951, The Theory of International Economic Policy, Volume I: The Balance of Payments, Oxford University Press, London.

Meade, JE 1955, The Theory of International Economic Policy, Volume II: Trade and Welfare, Oxford University Press, London.

Meade, JE 1956, 'The Price Mechanism and the Australian Balance of Payments', Economic Record, vol. 32, no. 2, pp. 239-256.

Meade, JE 1977a, Autobiography. Available from:

<http://www.nobelprize.org/nobel_prizes/economics/laureates/1977/meadeautobio.html?print=1>. [18 January 2013].

Meade, JE 1977b, The Meaning of "Internal Balance". Available from: $<$ http://www.nobelprize.org/nobel_prizes/economics/laureates/1977/meadelecture.html>. [18 January 2013].

Metzler, LA 1948, 'The Theory of International Trade', in A Survey of Contemporary Economics, ed. HS Ellis, Richard D. Irwin, Inc., Homewood, Illinois, pp. 210-254.

Mill, JS 1871, Principles of Political Economy with some of their Applications to Social Philosophy, 7th edn, Longman, London.

Mundell, RA 1962, 'The Appropriate Use of Monetary and Fiscal Policy for Internal and External Stability', Staff Papers - International Monetary Fund, vol. 9, no. 1, pp. 7079.

Mundell, RA 1968, International Economics, Macmillan, New York.

Mussa, M 1974, 'Tariffs and the Distribution of Income: The Importance of Factor Specificity, Substitutability, and Intensity in the Short and Long Run', Journal of Political Economy, vol. 82, no. 6, pp. 1191-1203.

Ohlin, B 1929, 'The Reparation Problem: A Discussion', The Economic Journal, vol. 39, no. 154, pp. 172-182.

Oppenheimer, PM 1974, 'Non-Traded Goods and the Balance of Payments: A Historical Note', Journal of Economic Literature, vol. 12, no. 3, pp. 882-888.

Pearce, IF 1961, 'The Problem of the Balance of Payments', International Economic Review, vol. 2, no. 1, pp. 1-28.

Pitchford, J 2002, Salter, Wilfred Edward Graham (1929-1963) in Australian Dictionary of Biography, Australian National University, Online Edition, [16 April 2013].

Polak, JJ 1957, 'Monetary Analysis of Income Formation and Payments Problems', Staff Papers - International Monetary Fund, vol. 6, no. 1, pp. 1-50. 
Porter, MG 1978, 'External Shocks and Stabilization Policy in a Small Open Economy: The Australian Experience', Weltwirtschaftliches Archiv, vol. 114, no. 4, pp. 709-735.

Reinhart, CM \& Reinhart, VR 2008, 'Capital Flow Bonanzas: An Encompassing View of the Past and Present', NBER International Seminar on Macroeconomics, vol. 5, no. 1, pp. $9-62$.

Reserve Bank of Australia 1997, 4.15 Unemployment. Available from: <http://www.rba.gov.au/statistics/frequency/occ-paper-8.html>. [3 April 2013].

Robinson, J 1937, Essays in the Theory of Employment, Macmillan, London.

Sachs, JD 1999, 'Creditor Panics: Causes and Remedies', Cato Journal, vol. 18, no. 3, pp. 377-390.

Salter, WEG 1959, 'Internal and External Balance: The Role of Price and Expenditure Effects', Economic Record, vol. 35, no. 71, pp. 226-238.

Salter, WEG 1966, Productivity and Technical Change, 2nd edn, Cambridge University Press, Cambridge.

Samuelson, PA 1971, 'Ohlin Was Right', The Swedish Journal of Economics, vol. 73, no. 4, pp. 365-384.

Snape, RH 1977, 'Effects of Mineral Development on the Economy', Australian Journal of Agricultural Economics, vol. 21, no. 3, pp. 147-156.

Swan, PL 2006, Trevor Winchester Swan AO. Available from: $<$ https://crawford.anu.edu.au/pdf/seminars/trevor_swan.pdf $>$. [18 January 2013].

Swan, TW 1960, 'Economic Control in a Dependent Economy', Economic Record, vol. 36, no. 73, pp. 51-66.

Swan, TW 1963a, 'Longer-Run Problems of the Balance of Payments', in The Australian Economy: A Volume of Readings, eds HW Arndt \& WM Corden, Cheshire, Melbourne.

Swan, TW 1963b, 'Wilfred Edward Graham Salter: 1929-1963', Economic Record, vol. 39, no. 88, pp. 486-487.

Taussig, FW 1917, 'International Trade Under Depreciated Paper. A Contribution to Theory', The Quarterly Journal of Economics, vol. 31, no. 3, pp. 380-403.

Taussig, FW 1920, 'Germany's Reparation Payments', The American Economic Review, vol. 10, no. 1 , pp. 33-49.

Taussig, FW 1927, International Trade, The Macmillan Company, New York.

Tinbergen, J 1952, On the Theory of Economic Policy, North-Holland, Amsterdam. 
Viner, J 1924, Canada's Balance of International Indebtedness 1900-1913: An Inductive Study in the Theory of International Trade, Harvard University Press, Cambridge.

Viner, J 1932, 'Cost Curves and Supply Curves', Zeitschrift für Nationalökonomie, vol. 3, no. 1, pp. 23-46.

Viner, J 1937, Studies in the Theory of International Trade, Allen \& Unwin, London.

Weber, EJ 2011, 'Wilfred E.G. Salter: The Merits of a Classical Economic Education', History of Economics Review, no. 54, pp. 111-130.

Wilson, R 1931, Capital Imports and the Terms of Trade, Melbourne University Press in association with Macmillan, Melbourne. 
Editor, UWA Economics Discussion Papers:

Ernst Juerg Weber

Business School - Economics

University of Western Australia

35 Sterling Hwy

Crawley WA 6009

Australia

Email: ecoadmin@biz.uwa.edu.au

The Economics Discussion Papers are available at:

1980 - 2002: http://ecompapers.biz.uwa.edu.au/paper/PDF\%20of\%20Discussion\%20Papers/

Since 2001: http://ideas.repec.org/s/uwa/wpaper1.html

Since 2004: $\quad$ http://www.business.uwa.edu.au/school/disciplines/economics

\begin{tabular}{|c|c|c|}
\hline \multicolumn{3}{|c|}{$\begin{array}{l}\text { ECONOMICS DISCUSSION PAPERS } \\
2011\end{array}$} \\
\hline $\begin{array}{l}\text { DP } \\
\text { NUMBER }\end{array}$ & AUTHORS & TITLE \\
\hline 11.01 & Robertson, P.E. & $\begin{array}{l}\text { DEEP IMPACT: CHINA AND THE WORLD } \\
\text { ECONOMY }\end{array}$ \\
\hline 11.02 & Kang, C. and Lee, S.H. & $\begin{array}{l}\text { BEING KNOWLEDGEABLE OR SOCIABLE? } \\
\text { DIFFERENCES IN RELATIVE IMPORTANCE OF } \\
\text { COGNITIVE AND NON-COGNITIVE SKILLS }\end{array}$ \\
\hline 11.03 & Turkington, D. & DIFFERENT CONCEPTS OF MATRIX CALCULUS \\
\hline 11.04 & Golley, J. and Tyers, R. & $\begin{array}{l}\text { CONTRASTING GIANTS: DEMOGRAPHIC CHANGE } \\
\text { AND ECONOMIC PERFORMANCE IN CHINA AND } \\
\text { INDIA }\end{array}$ \\
\hline 11.05 & Collins, J., Baer, B. and Weber, E.J. & $\begin{array}{l}\text { ECONOMIC GROWTH AND EVOLUTION: } \\
\text { PARENTAL PREFERENCE FOR QUALITY AND } \\
\text { QUANTITY OF OFFSPRING }\end{array}$ \\
\hline 11.06 & Turkington, D. & $\begin{array}{l}\text { ON THE DIFFERENTIATION OF THE LOG } \\
\text { LIKELIHOOD FUNCTION USING MATRIX } \\
\text { CALCULUS }\end{array}$ \\
\hline 11.07 & Groenewold, N. and Paterson, J.E.H. & $\begin{array}{l}\text { STOCK PRICES AND EXCHANGE RATES IN } \\
\text { AUSTRALIA: ARE COMMODITY PRICES THE } \\
\text { MISSING LINK? }\end{array}$ \\
\hline 11.08 & Chen, A. and Groenewold, N. & $\begin{array}{l}\text { REDUCING REGIONAL DISPARITIES IN CHINA: IS } \\
\text { INVESTMENT ALLOCATION POLICY EFFECTIVE? }\end{array}$ \\
\hline 11.09 & Williams, A., Birch, E. and Hancock, P. & $\begin{array}{l}\text { THE IMPACT OF ON-LINE LECTURE RECORDINGS } \\
\text { ON STUDENT PERFORMANCE }\end{array}$ \\
\hline 11.10 & Pawley, J. and Weber, E.J. & $\begin{array}{l}\text { INVESTMENT AND TECHNICAL PROGRESS IN THE } \\
\text { G7 COUNTRIES AND AUSTRALIA }\end{array}$ \\
\hline 11.11 & Tyers, R. & $\begin{array}{l}\text { AN ELEMENTAL MACROECONOMIC MODEL FOR } \\
\text { APPLIED ANALYSIS AT UNDERGRADUATE LEVEL }\end{array}$ \\
\hline 11.12 & Clements, K.W. and Gao, G. & QUALITY, QUANTITY, SPENDING AND PRICES \\
\hline 11.13 & Tyers, R. and Zhang, Y. & $\begin{array}{l}\text { JAPAN'S ECONOMIC RECOVERY: INSIGHTS FROM } \\
\text { MULTI-REGION DYNAMICS }\end{array}$ \\
\hline
\end{tabular}




\begin{tabular}{|c|c|c|}
\hline 11.14 & McLure, M. & A. C. PIGOU'S REJECTION OF PARETO'S LAW \\
\hline 11.15 & Kristoffersen, I. & $\begin{array}{l}\text { THE SUBJECTIVE WELLBEING SCALE: HOW } \\
\text { REASONABLE IS THE CARDINALITY } \\
\text { ASSUMPTION? }\end{array}$ \\
\hline 11.16 & Clements, K.W., Izan, H.Y. and Lan, Y. & VOLATILITY AND STOCK PRICE INDEXES \\
\hline 11.17 & Parkinson, $\mathrm{M}$. & $\begin{array}{l}\text { SHANN MEMORIAL LECTURE 2011: SUSTAINABLE } \\
\text { WELLBEING - AN ECONOMIC FUTURE FOR } \\
\text { AUSTRALIA }\end{array}$ \\
\hline 11.18 & Chen, A. and Groenewold, N. & $\begin{array}{l}\text { THE NATIONAL AND REGIONAL EFFECTS OF } \\
\text { FISCAL DECENTRALISATION IN CHINA }\end{array}$ \\
\hline 11.19 & Tyers, R. and Corbett, J. & $\begin{array}{l}\text { JAPAN'S ECONOMIC SLOWDOWN AND ITS } \\
\text { GLOBAL IMPLICATIONS: A REVIEW OF THE } \\
\text { ECONOMIC MODELLING }\end{array}$ \\
\hline 11.20 & $\mathrm{Wu}, \mathrm{Y}$. & $\begin{array}{l}\text { GAS MARKET INTEGRATION: GLOBAL TRENDS } \\
\text { AND IMPLICATIONS FOR THE EAS REGION }\end{array}$ \\
\hline 11.21 & Fu, D., Wu, Y. and Tang, Y. & $\begin{array}{l}\text { DOES INNOVATION MATTER FOR CHINESE HIGH- } \\
\text { TECH EXPORTS? A FIRM-LEVEL ANALYSIS }\end{array}$ \\
\hline 11.22 & Fu, D. and Wu, Y. & $\begin{array}{l}\text { EXPORT WAGE PREMIUM IN CHINA'S } \\
\text { MANUFACTURING SECTOR: A FIRM LEVEL } \\
\text { ANALYSIS }\end{array}$ \\
\hline 11.23 & Li, B. and Zhang, J. & $\begin{array}{l}\text { SUBSIDIES IN AN ECONOMY WITH ENDOGENOUS } \\
\text { CYCLES OVER NEOCLASSICAL INVESTMENT AND } \\
\text { NEO-SCHUMPETERIAN INNOVATION REGIMES }\end{array}$ \\
\hline 11.24 & Krey, B., Widmer, P.K. and Zweifel, P. & $\begin{array}{l}\text { EFFICIENT PROVISION OF ELECTRICITY FOR THE } \\
\text { UNITED STATES AND SWITZERLAND }\end{array}$ \\
\hline 11.25 & $\mathrm{Wu}, \mathrm{Y}$. & $\begin{array}{l}\text { ENERGY INTENSITY AND ITS DETERMINANTS IN } \\
\text { CHINA'S REGIONAL ECONOMIES }\end{array}$ \\
\hline
\end{tabular}




\begin{tabular}{|c|c|c|}
\hline \multicolumn{3}{|c|}{$\begin{array}{l}\text { ECONOMICS DISCUSSION PAPERS } \\
2012\end{array}$} \\
\hline $\begin{array}{l}\text { DP } \\
\text { NUMBER }\end{array}$ & AUTHORS & TITLE \\
\hline 12.01 & $\begin{array}{l}\text { Clements, K.W., Gao, G., and } \\
\text { Simpson, T. }\end{array}$ & $\begin{array}{l}\text { DISPARITIES IN INCOMES AND PRICES } \\
\text { INTERNATIONALLY }\end{array}$ \\
\hline 12.02 & Tyers, R. & $\begin{array}{l}\text { THE RISE AND ROBUSTNESS OF ECONOMIC FREEDOM } \\
\text { IN CHINA }\end{array}$ \\
\hline 12.03 & Golley, J. and Tyers, R. & $\begin{array}{l}\text { DEMOGRAPHIC DIVIDENDS, DEPENDENCIES AND } \\
\text { ECONOMIC GROWTH IN CHINA AND INDIA }\end{array}$ \\
\hline 12.04 & Tyers, R. & LOOKING INWARD FOR GROWTH \\
\hline 12.05 & Knight, K. and McLure, M. & THE ELUSIVE ARTHUR PIGOU \\
\hline 12.06 & McLure, M. & $\begin{array}{l}\text { ONE HUNDRED YEARS FROM TODAY: A. C. PIGOU'S } \\
\text { WEALTH AND WELFARE }\end{array}$ \\
\hline 12.07 & Khuu, A. and Weber, E.J. & HOW AUSTRALIAN FARMERS DEAL WITH RISK \\
\hline 12.08 & Chen, M. and Clements, K.W. & PATTERNS IN WORLD METALS PRICES \\
\hline 12.09 & Clements, K.W. & UWA ECONOMICS HONOURS \\
\hline 12.10 & Golley, J. and Tyers, R. & $\begin{array}{l}\text { CHINA'S GENDER IMBALANCE AND ITS ECONOMIC } \\
\text { PERFORMANCE }\end{array}$ \\
\hline 12.11 & Weber, E.J. & $\begin{array}{l}\text { AUSTRALIAN FISCAL POLICY IN THE AFTERMATH OF } \\
\text { THE GLOBAL FINANCIAL CRISIS }\end{array}$ \\
\hline 12.12 & Hartley, P.R. and Medlock III, K.B. & $\begin{array}{l}\text { CHANGES IN THE OPERATIONAL EFFICIENCY OF } \\
\text { NATIONAL OIL COMPANIES }\end{array}$ \\
\hline 12.13 & Li, L. & $\begin{array}{l}\text { HOW MUCH ARE RESOURCE PROJECTS WORTH? A } \\
\text { CAPITAL MARKET PERSPECTIVE }\end{array}$ \\
\hline 12.14 & Chen, A. and Groenewold, N. & $\begin{array}{l}\text { THE REGIONAL ECONOMIC EFFECTS OF A } \\
\text { REDUCTION IN CARBON EMISSIONS AND AN } \\
\text { EVALUATION OF OFFSETTING POLICIES IN CHINA }\end{array}$ \\
\hline 12.15 & Collins, J., Baer, B. and Weber, E.J. & $\begin{array}{l}\text { SEXUAL SELECTION, CONSPICUOUS CONSUMPTION } \\
\text { AND ECONOMIC GROWTH }\end{array}$ \\
\hline 12.16 & Wu, Y. & TRENDS AND PROSPECTS IN CHINA'S R\&D SECTOR \\
\hline 12.17 & Cheong, T.S. and Wu, Y. & $\begin{array}{l}\text { INTRA-PROVINCIAL INEQUALITY IN CHINA: AN } \\
\text { ANALYSIS OF COUNTY-LEVEL DATA }\end{array}$ \\
\hline 12.18 & Cheong, T.S. & THE PATTERNS OF REGIONAL INEQUALITY IN CHINA \\
\hline 12.19 & Wu, Y. & $\begin{array}{l}\text { ELECTRICITY MARKET INTEGRATION: GLOBAL } \\
\text { TRENDS AND IMPLICATIONS FOR THE EAS REGION }\end{array}$ \\
\hline 12.20 & Knight, K. & $\begin{array}{l}\text { EXEGESIS OF DIGITAL TEXT FROM THE HISTORY OF } \\
\text { ECONOMIC THOUGHT: A COMPARATIVE } \\
\text { EXPLORATORY TEST }\end{array}$ \\
\hline 12.21 & Chatterjee, I. & $\begin{array}{l}\text { COSTLY REPORTING, EX-POST MONITORING, AND } \\
\text { COMMERCIAL PIRACY: A GAME THEORETIC } \\
\text { ANALYSIS }\end{array}$ \\
\hline 12.22 & Pen, S.E. & QUALITY-CONSTANT ILLICIT DRUG PRICES \\
\hline 12.23 & Cheong, T.S. and Wu, Y. & $\begin{array}{l}\text { REGIONAL DISPARITY, TRANSITIONAL DYNAMICS } \\
\text { AND CONVERGENCE IN CHINA }\end{array}$ \\
\hline
\end{tabular}




\begin{tabular}{|l|l|l|}
\hline 12.24 & Ezzati, P. & $\begin{array}{l}\text { FINANCIAL MARKETS INTEGRATION OF IRAN } \\
\text { WITHIN THE MIDDLE EAST AND WITH THE REST OF } \\
\text { THE WORLD }\end{array}$ \\
\hline 12.25 & Kwan, F., Wu, Y. and Zhuo, S. & $\begin{array}{l}\text { RE-EXAMINATION OF THE SURPLUS AGRICULTURAL } \\
\text { LABOUR IN CHINA }\end{array}$ \\
\hline 12.26 & Wu, Y. & R\&D BEHAVIOUR IN CHINESE FIRMS \\
\hline 12.27 & Tang, S.H.K. and Yung, L.C.W. & $\begin{array}{l}\text { MAIDS OR MENTORS? THE EFFECTS OF LIVE-IN } \\
\text { FOREIGN DOMESTIC WORKERS ON SCHOOL } \\
\text { CHILDREN'S EDUCATIONAL ACHIEVEMENT IN HONG } \\
\text { KONG }\end{array}$ \\
\hline 12.28 & Groenewold, N. & $\begin{array}{l}\text { AUSTRALIA AND THE GFC: SAVED BY ASTUTE } \\
\text { FISCAL POLICY? }\end{array}$ \\
\hline
\end{tabular}

\begin{tabular}{|c|c|c|}
\hline \multicolumn{3}{|c|}{$\begin{array}{c}\text { ECONOMICS DISCUSSION PAPERS } \\
2013\end{array}$} \\
\hline $\begin{array}{l}\text { DP } \\
\text { NUMBER }\end{array}$ & AUTHORS & TITLE \\
\hline 13.01 & $\begin{array}{l}\text { Chen, M., Clements, K.W. and } \\
\text { Gao, G. }\end{array}$ & THREE FACTS ABOUT WORLD METAL PRICES \\
\hline 13.02 & Collins, J. and Richards, O. & $\begin{array}{l}\text { EVOLUTION, FERTILITY AND THE AGEING } \\
\text { POPULATION }\end{array}$ \\
\hline 13.03 & $\begin{array}{l}\text { Clements, K., Genberg, H., } \\
\text { Harberger, A., Lothian, J., } \\
\text { Mundell, R., Sonnenschein, H. and } \\
\text { Tolley, G. }\end{array}$ & LARRY SJAASTAD, 1934-2012 \\
\hline 13.04 & Robitaille, M.C. and Chatterjee, I. & MOTHERS-IN-LAW AND SON PREFERENCE IN INDIA \\
\hline 13.05 & Clements, K.W. and Izan, I.H.Y. & $\begin{array}{l}\text { REPORT ON THE } 25^{\mathrm{TH}} \text { PHD CONFERENCE IN } \\
\text { ECONOMICS AND BUSINESS }\end{array}$ \\
\hline 13.06 & Walker, A. and Tyers, R. & QUANTIFYING AUSTRALIA’S “THREE SPEED” BOOM \\
\hline 13.07 & Yu, F. and Wu, Y. & PATENT EXAMINATION AND DISGUISED PROTECTION \\
\hline 13.08 & $\mathrm{Yu}, \mathrm{F}$. and $\mathrm{Wu}, \mathrm{Y}$. & $\begin{array}{l}\text { PATENT CITATIONS AND KNOWLEDGE SPILLOVERS: } \\
\text { AN ANALYSIS OF CHINESE PATENTS REGISTER IN } \\
\text { THE US }\end{array}$ \\
\hline 13.09 & Chatterjee, I. and Saha, B. & BARGAINING DELEGATION IN MONOPOLY \\
\hline 13.10 & Cheong, T.S. and Wu, Y. & $\begin{array}{l}\text { GLOBALIZATION AND REGIONAL INEQUALITY IN } \\
\text { CHINA }\end{array}$ \\
\hline 13.11 & Cheong, T.S. and Wu, Y. & INEQUALITY AND CRIME RATES IN CHINA \\
\hline 13.12 & Robertson, P.E. and Ye, L. & ON THE EXISTENCE OF A MIDDLE INCOME TRAP \\
\hline 13.13 & Robertson, P.E. & THE GLOBAL IMPACT OF CHINA’S GROWTH \\
\hline 13.14 & $\begin{array}{l}\text { Hanaki, N., Jacquemet, N., } \\
\text { Luchini, S., and Zylbersztejn, A. }\end{array}$ & $\begin{array}{l}\text { BOUNDED RATIONALITY AND STRATEGIC } \\
\text { UNCERTAINTY IN A SIMPLE DOMINANCE SOLVABLE } \\
\text { GAME }\end{array}$ \\
\hline 13.15 & $\begin{array}{l}\text { Okatch, Z., Siddique, A. and } \\
\text { Rammohan, A. }\end{array}$ & $\begin{array}{l}\text { DETERMINANTS OF INCOME INEQUALITY IN } \\
\text { BOTSWANA }\end{array}$ \\
\hline
\end{tabular}




\begin{tabular}{|c|c|c|}
\hline 13.16 & Clements, K.W. and Gao, G. & $\begin{array}{l}\text { A MULTI-MARKET APPROACH TO MEASURING THE } \\
\text { CYCLE }\end{array}$ \\
\hline 13.17 & Chatterjee, I. and Ray, R. & $\begin{array}{l}\text { THE ROLE OF INSTITUTIONS IN THE INCIDENCE OF } \\
\text { CRIME AND CORRUPTION }\end{array}$ \\
\hline 13.18 & Fu, D. and Wu, Y. & $\begin{array}{l}\text { EXPORT SURVIVAL PATTERN AND DETERMINANTS } \\
\text { OF CHINESE MANUFACTURING FIRMS }\end{array}$ \\
\hline 13.19 & Shi, X., Wu, Y. and Zhao, D. & $\begin{array}{l}\text { KNOWLEDGE INTENSIVE BUSINESS SERVICES AND } \\
\text { THEIR IMPACT ON INNOVATION IN CHINA }\end{array}$ \\
\hline 13.20 & $\begin{array}{l}\text { Tyers, R., Zhang, Y. and } \\
\text { Cheong, T.S. }\end{array}$ & $\begin{array}{l}\text { CHINA’S SAVING AND GLOBAL ECONOMIC } \\
\text { PERFORMANCE }\end{array}$ \\
\hline 13.21 & Collins, J., Baer, B. and Weber, E.J. & $\begin{array}{l}\text { POPULATION, TECHNOLOGICAL PROGRESS AND THE } \\
\text { EVOLUTION OF INNOVATIVE POTENTIAL }\end{array}$ \\
\hline 13.22 & Hartley, P.R. & THE FUTURE OF LONG-TERM LNG CONTRACTS \\
\hline 13.23 & Tyers, R. & $\begin{array}{l}\text { A SIMPLE MODEL TO STUDY GLOBAL } \\
\text { MACROECONOMIC INTERDEPENDENCE }\end{array}$ \\
\hline 13.24 & McLure, M. & $\begin{array}{l}\text { REFLECTIONS ON THE QUANTITY THEORY: PIGOU IN } \\
1917 \text { AND PARETO IN 1920-21 }\end{array}$ \\
\hline 13.25 & Chen, A. and Groenewold, N. & $\begin{array}{l}\text { REGIONAL EFFECTS OF AN EMISSIONS-REDUCTION } \\
\text { POLICY IN CHINA: THE IMPORTANCE OF THE } \\
\text { GOVERNMENT FINANCING METHOD }\end{array}$ \\
\hline 13.26 & Siddique, M.A.B. & $\begin{array}{l}\text { TRADE RELATIONS BETWEEN AUSTRALIA AND } \\
\text { THAILAND: } 1990 \text { TO } 2011\end{array}$ \\
\hline 13.27 & Li, B. and Zhang, J. & $\begin{array}{l}\text { GOVERNMENT DEBT IN AN INTERGENERATIONAL } \\
\text { MODEL OF ECONOMIC GROWTH, ENDOGENOUS } \\
\text { FERTILITY, AND ELASTIC LABOR WITH AN } \\
\text { APPLICATION TO JAPAN }\end{array}$ \\
\hline 13.28 & Robitaille, M. and Chatterjee, I. & $\begin{array}{l}\text { SEX-SELECTIVE ABORTIONS AND INFANT } \\
\text { MORTALITY IN INDIA: THE ROLE OF PARENTS' } \\
\text { STATED SON PREFERENCE }\end{array}$ \\
\hline 13.29 & Ezzati, P. & $\begin{array}{l}\text { ANALYSIS OF VOLATILITY SPILLOVER EFFECTS: } \\
\text { TWO-STAGE PROCEDURE BASED ON A MODIFIED } \\
\text { GARCH-M }\end{array}$ \\
\hline 13.30 & Robertson, P. E. & $\begin{array}{l}\text { DOES A FREE MARKET ECONOMY MAKE AUSTRALIA } \\
\text { MORE OR LESS SECURE IN A GLOBALISED WORLD? }\end{array}$ \\
\hline 13.31 & $\begin{array}{l}\text { Das, S., Ghate, C. and } \\
\text { Robertson, P. E. }\end{array}$ & $\begin{array}{l}\text { REMOTENESS AND UNBALANCED GROWTH: } \\
\text { UNDERSTANDING DIVERGENCE ACROSS INDIAN } \\
\text { DISTRICTS }\end{array}$ \\
\hline 13.32 & Robertson, P.E. and Sin, A. & $\begin{array}{l}\text { MEASURING HARD POWER: CHINA’S ECONOMIC } \\
\text { GROWTH AND MILITARY CAPACITY }\end{array}$ \\
\hline 13.33 & Wu, Y. & $\begin{array}{l}\text { TRENDS AND PROSPECTS FOR THE RENEWABLE } \\
\text { ENERGY SECTOR IN THE EAS REGION }\end{array}$ \\
\hline 13.34 & $\begin{array}{l}\text { Yang, S., Zhao, D., Wu, Y. and } \\
\text { Fan, J. }\end{array}$ & $\begin{array}{l}\text { REGIONAL VARIATION IN CARBON EMISSION AND } \\
\text { ITS DRIVING FORCES IN CHINA: AN INDEX } \\
\text { DECOMPOSITION ANALYSIS }\end{array}$ \\
\hline
\end{tabular}




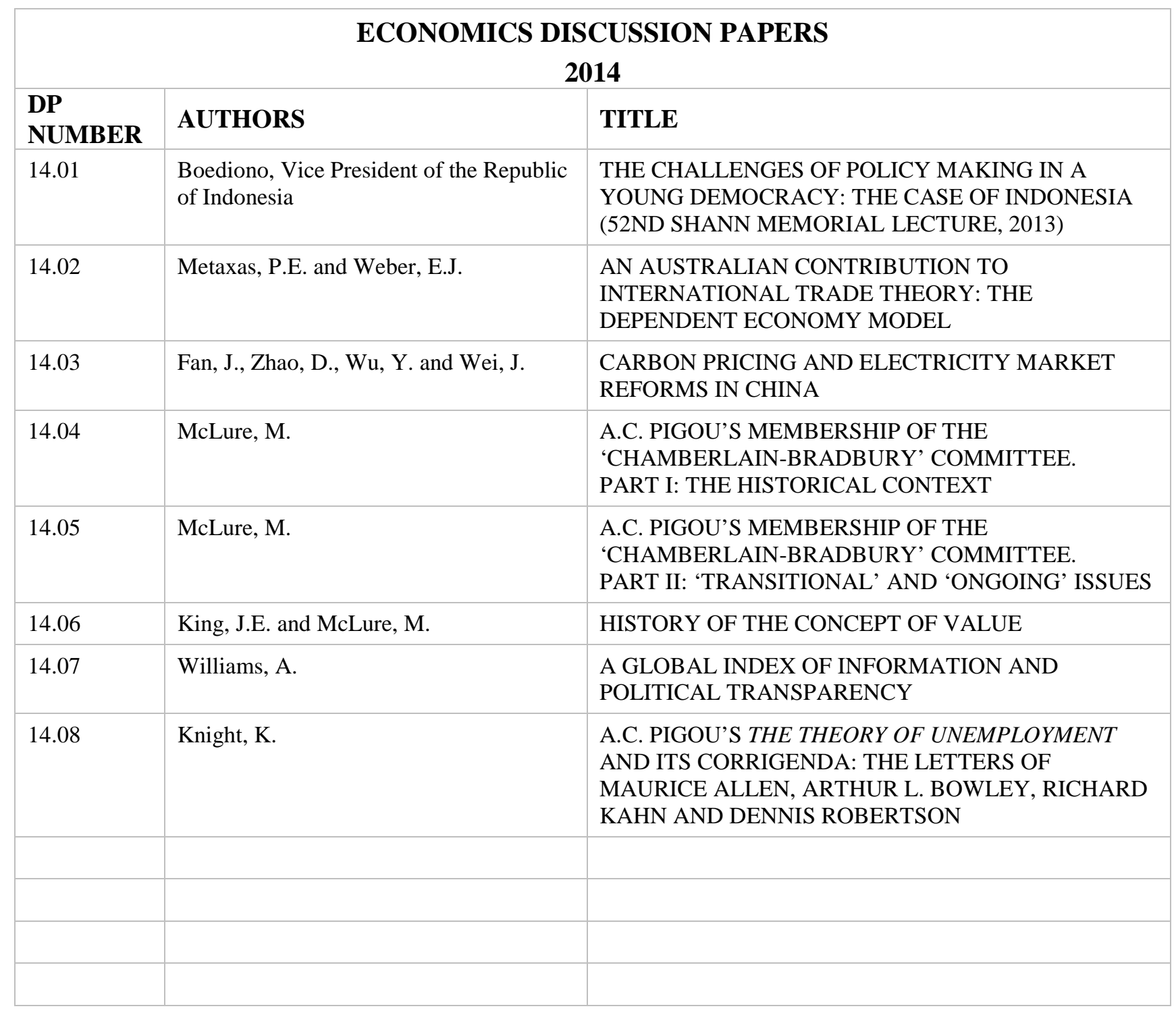

